\title{
Adramytteion Antik Kenti Bütüncül Koruma Planı
}

\author{
Adramytteion Ancient City Comprehensive \\ Heritage Preservation Plan
}

Seher Başlık, ${ }^{1}$ (D) Mehmet Rıfat Akbulut ${ }^{2}$

${ }^{1}$ Mimar Sinan Güzel Sanatlar Üniversitesi, Enformatik Bölümü, Enformatik Anabilim Dalı, İstanbul

${ }^{2}$ Mimar Sinan Güzel Sanatlar Üniversitesi, Mimarlık Fakültesi, Şehir ve Bölge Planlama Bölümü, Kentsel Koruma ve Yenileme Bilim Dalı, İstanbul

\section{ÖZ}

Balıkesir İli, Burhaniye İlçesi, Ören Mahallesi Adramytteion Antik Kenti Arkeolojik Sit Alanı Türkiye'de birçok örneğine rastlanan farklı dönemlere ait kültür izlerinin tabakalaştı̆̆ı yerleşme alanlarından biridir. Yerleşim sürekliliği gösteren bu tür arkeolojik sitlerde kültürel mirasın korunması ve bilimsel arkeolojik araştırma faaliyetlerinin yürütülmesi daha zor ve çok çeşitli koruma bileşenini değerlendirmeyi gerektirir. Ayrıca, 2I. yüzyılda uluslararası düzeyde yeniden şekillenen koruma bakış açısı ile tanımlanan yeni ilkeler ve kavramlar, tarihi, doğal ve kültürel çevrelerin bütüncül şekilde ele alınmasıyla çağdaş gelişmenin miras değerlerine karşıt olmadığı vurgulanmakta, kentsel mirasın koruma hedefleri ile toplumsal ve ekonomik hedeflerini bütünleştirmektedir. Farklı dönemlere ait kültür izlerinin tabakalaştığı yerleşme alanları için önemli açılımlar getiren uluslararası düzeyde koruma anlayışındaki yeni ilke ve kavramlar makalede, Adramytteion Antik Kenti Arkeolojik Sit Alanı Koruma Amaçlı İmar Planı amaç ve ilkeleri çerçevesinde değerlendirilmektedir. Makale kapsamında Ören/ Adramytteion Arkeolojik Sit Alanı ve yakın çevresinde kültür mirası ile günümüz yaşamının bütünsel olarak ele alan, gerek arkeolojik araştırma ve kültür mirasının, gerekse yerleşmedeki mevcut yaşamın sürekliliğini yani sürdürülebilirliğini benimseyen koruma planlaması deneyimi paylaşılmakta ve bir örnek olması amacıyla tartışılmaktadır.

Anahtar sözcükler: Adramytteion; arkeolojik sit alanları; koruma planlaması; kültürel miras.

\begin{abstract}
Adramytteion Ancient City is situated at the Gulf of Edremit in North Aegean, on the shoreline of Ören neighbourhood of the town of Burhaniye of Balıkesir Province. Adramytteion/Ören is one of archaeological sites and settlements where various cultures and civilisations from different historical periods are layered. Preservation of cultural heritage and permanence of archaeologic researches in such places with a continuum of habitation is highly difficult and necessities consideration of a variety of planning component. On the other hand, due to new approaches to preservation of cultural heritage in $2 I^{\text {st }}$ century on international level and new principles and concepts particularly accentuate a comprehensive assessment of environments with historical, natural and cultural heritage values. Therefore, modern development is not always contradictory to preservation while these approaches integrates preservation of urban heritages with social and economical objectives. Here, new principles and concepts emerged from fresh approaches on international scale which brings important opportunities for places where a multitude of past cultures physically layered are tackled and discussed around the case of Adramytteion Ancient City Preservation Master Plan's objectives and principles. This plan is discussed here in order to provide a case of its own with almost considerable differences of mainstream preservation planning in Turkey since it seeks sustainability of archaeologic researches and cultural heritages as well as existing life of present neighbourhood.
\end{abstract}

Keywords: Adramytteion; archaeological sites; preservation planning; cultural heritage. 


\section{Giriş}

"Bizlere düşen, iyi, güzel ve doğru bildiklerimizi bizden sonraki kuşaklara sağlıklı bir şekilde aktarmaktır. Gelecek kuşakların değerleri, öncelikleri, anlayışları bizlerinkinden farklı olabilir; bizim değer verdiklerimiz onlar için değerini yitirebilir. Yine de görev ve sorumluluğumuz değerli bildiklerimizi bizden sonrakilere olabildiğince sağlam ve doğru bir şekilde aktarmaktır.” (2. yazar, 20।4)

Balıkesir İli, Burhaniye İlçesi, Ören Mahallesi Adramytteion Antik Kenti Arkeolojik Sit Alanı ve yakın çevresinde gecikmiş bir yasal gereklilik ve zorunluluk olarak başlayan koruma plan çalışması, Türkiye'deki genel koruma anlayışı ve koruma planlaması yaklaşımlarından farklılaşan bir örnek olarak biçimlendikten sonra, hazırlık ve onay sürecinde giderek çekişmeli bir koruma maratonuna dönüşür. Adramytteion antik kenti Arkeolojik Sit Alanı, günümüz yerleşmesiyle bütünleşmiş, farklı dönemlere ait kültür izlerinin tabakalaştığı yerleşme alanlarındandır ve Arkeolojik Sit Alanı'nda yer alan korunması gerekli değerlerin nitelik, durum ve ölçek açısından sunduğu çeşitlilik, korumada 2 I. yüzyılda yeniden şekillenen yaklaşımları, çeşitli önlemleri bir arada değerlendirmeyi ve farklı duyarlıkları yansıtan plan kararlarını gerektiren özellikleri içerir. Bu sebeple makalenin amacı, Türkiye'de birçok örneğine rastlanan, farklı dönemlere ait kültür izlerinin tabakalaştığı yerleşme alanlarında bir koruma planlaması deneyimini paylaşmak ve bu koruma yaklaşımını bir öneri olarak tartışmaktır.

Antik kentler ile aynı konumda bulunan kırsal veya kentsel yerleşmeler, yani farklı dönemlere ait kültür izlerinin tabakalaştığı yerleşme alanları, ortak bir ifade ile çok katmanlı kentler olarak nitelendirilerek incelenmiştir (Bilgin Altınöz, 2002; Belge, 2005; Karabağ; 2008; Çırak, 20 I0; Binan, 20I3;). Yaşam sürekliliği gösteren günümüzde de kullanılan bu kentler kültürel, sosyal, ekonomik, teknik olarak birçok dönemin değerlerinin öğrenilerek yaşamın bir parçası haline gelmesini sağlar; insanlık tarihine ilişkin büyük bilgi birikiminin devamlılı̆ı̆na imkân verir. Bu noktada bir süreç içinde birbirine eklemlenerek bir yaşam zenginliği yaratan yerleşimlerin nasıl korunacağı hangi kültürel mirasın daha üstün bir değere sahip olduğu önem kazanmaktadır. Kimi zaman kentleşme baskısı ve büyük projelerle kültürel dokular tahrip olurken kimi zaman da farklı kültür dokuları arasında yeni, eski ve daha eski tercihleri bütünsel yapıya zarar vermektedir. Bu yapıya bir de doğal peyzaj ögeleri dahil edildiğinde korunacak değerlerin kapsamı daha da genişlemektedir. Ayrıca yerleşim sürekliliği gösteren arkeolojik sitlerde bilimsel araştırma, kazı ve koruma çalışmaları daha zor ve maliyetlidir. Mevcut yerleşik yaşam ile arkeolojik bilimsel araştırma ve kazı çalışmaları için gerekli şartların sağlanması, çıkan eserlerin koruma altına alınarak sergilenmesi ve tarihsel bilgiyi toplum ile paylaşmak için gerekli mekânsal düzenlemelerin düşünülerek kent yaşamına dahil edilmesi gerekir. Diğer bir deyişle gerek arkeolojik araştırma ve kültür mirasının, gerekse yerleşmedeki mevcut yaşamın sürekliliği yani sürdürülebilirliği sağlanmalıdır. Çok katmanlı kentlerde kültürel mirasın sürdürülebilirliğinin sağlanması için ulusal yasal yönetsel sistemin, uluslararası, sözleşme ve tüzükleri gözeterek geliştirilmesine de ihtiyaç vardır. Bu sebeple ülkemizde arkeolojik sit alanlarında görülen çelişkiler makale kapsamında bir koruma plan uygulaması üzerinden tartışılarak, değerlendirilmektedir.

\section{Farklı Dönemlere Ait Kültür İzlerinin Tabakalaştığı Yerleşme Alanlarında Koruma}

1983 tarihli 2863 sayılı Kültür ve Tabiat Varlıklarını Koruma Kanunu halihazırda ülkemizde kültür mirasının koruma altına alınması ve değerlendirilerek toplum yaşamına kazandırılmasında uygulamanın yasal çerçevesini belirlemektedir. 2863 sayılı kanun ile kültür mirası, yapılan tespitlere bağlı olarak koruma bölge kurulu kararı ile tescillenmekte ve tescillenen kültür mirası için koruma esasları ve kullanım şartları Koruma Kurulları tarafından belirlenmektedir (KTB, 1983). 2863 sayılı kanunun 17. maddesine göre tescillenen kültür mirası bir alan ise sit alanı olarak ilan edilir. Bir alanın koruma bölge kurulunca sit olarak ilanı, her ölçekteki plan uygulamasını durdurur ve 3 yıl içinde koruma amaçlı imar planı yapılması zorunluluğu gelir. Sit alanlarında koruma ve kullanma ilke ve esaslarını belirleyen koruma kurulları sit alanları için hazırlanan plan ve projeleri inceleyerek onaylar. Böylece koruma kurulu ilke ve esaslarına ve koruma amaçlı imar planı yapım yönetmeliğine uygun yapılan planlara bağlı olarak sit alanlarının koruma ve kullanma kararları belirlenmiş olur. Her ne kadar kanun, ilke ve yönetmelikler kültür varlıklarının korunmasına dair olsa da kentleşme oranlarında yükseliş, yeni ihtiyaçlar ile şekillenen yatırımlar ve turizm alanlarının büyüme talepleri gibi güncel yaşamın mekân gereksinimleri sebebiyle tarihi dokuların ve kültür varlıklarının tahrip olduğu görülmektedir. Kimi zaman da tarihi dokular günümüz kentsel yaşamından tamamen ayrıştırılarak, bakım ve onarımları yapılamamakta ve kentle bağlantısı koparak tahrip olmaktadır. Bu açıdan kültür varlıklarının içinde bulunduğu doğal, yapılı ve sosyal çevrenin önemi oldukça büyüktür. Kültür varlığının bulunduğu çevrenin geçmişte olduğu gibi günümüzde de bir yaşam alanı olması ve tarihi kültür mirasının günümüz yerleşmesinin bir parçası haline gelmesi koruma ve kullanma şartlarını etkileyen önemli bir unsurdur. Kültürel çevre alanları sürekli olarak karmaşıklaşma derecesi artarak zenginleşir, evrimsel bir gelişme dinamiği göstererek gelişir, bu sebeple fiziksel yaşam çevresinin de buna bağlı olarak geçmişte donması değil, geçmişteki ögeleri koruyarak zenginleşmesi ve gelişeceğinin buna bağlı öngörülmesi gerekir (Tekeli, 1989). Kültür mirası ülkemizde birçok alanda günümüz yaşamıyla çakışmakta; bu durum kimi zaman büyük bir kentin merkezinde kimi zaman çeperlerinde kimi zaman da ulaşım, baraj gibi altyapı projelerinde görülmektedir. Her durumda kendine özgü şartları ile değerlendirilerek kültür mirasının za- 
rar görmemesi için gerekli önlemlerin alınması doğru olacaktır. Bu aynı zamanda günümüz yaşamıyla kültür varlıklarının birlikteliğini, bu birlikteliğin nasıl değerlendirildiğinin, günümüz ve geçmişin aynı mekânda varlıklarını devam ettirmesi için nasıl bir bakış açısına gerek duyulduğunun irdelenmesidir. Farklı dönemlere ait kültür izlerinin tabakalaştığı yerleşme alanlarında korunmaya değer olanın ne olduğu ve nasıl korunacağı sorusu yani sadece kültür varlığının kendisi mi, yoksa bir yerleşim ve yaşam kültürü olarak çağdaş yaşamı da içeren çevresiyle bir bütün olarak mı değerlendirileceği düşünülmelidir. Ayrıca kültür varlığının kentsel alanın kimliğine katkıda bulunan çok önemli bir değer olduğu da görülmelidir. Bu soruların cevapları bakış açısına ve nasıl bir koruma anlayışının benimsendiğine bağlı olarak değişmekte ve koruma planlarında yer almaktadır. Nitekim bu farklılıklar ülkemizde hem koruma imar planlarında hem de uygulama aşamalarında görülmektedir. Uluslararası düzeyde koruma anlayışında yaşanan gelişmelere bakıldığında ise kentsel mirasın birbirinin ardılı olan ve yaşayan kültürlerin ürettiği değerlerin tarihsel bir katmanı tarafından belirlenen insanlık için sosyal, kültürel ve ekonomik birer değer olduğunu ve kendi çeşitliliği içinde kabul görmüş gelenek ve deneyimleri içerdiği dile getirilmektedir (UNESCO, 20II). Farklı dönemlere ait kültür izlerinin tabakalaştığı yerleşme alanlarında Kentsel Arkeoloji, Tarihi Kentsel Peyzaj gibi kavramların koruma anlayışına dahil edildiği ve özellikle 2000'li yıllardan sonra koruma anlayışının tekrar şekillenerek, korumanın geleneksel ayrımların kaybolduğu bütüncül bakış açısı ve sürdürülebilir kalkınmanın bir bileşeni olması gerektiği anlaşılmaktadır. Bu sebeple koruma planlarında amaç ve hedeflerin tespiti ve planın koruma anlayışının belirlenmesinde güncel bakış açılarının, yasa, tüzük, sözleşme ve tavsiye kararlarını da içerecek şekilde incelenmesi önemli olacaktır.

Venedik Tüzüğü 3. maddesinde (1964) “Anıtların korunmasında ve onarılmasındaki amaç, onları bir sanat eseri olduğu kadar, bir tarihi belge olarak da korumaktır." ifadesi, tarihi eserin insanlık tarihi için önemli bilgi içerdiğini ve eser veya eserlerin çevresiyle bir bütün içinde ve sadece bir eser olarak değil, bilgi kaynağı olarak da korunması gerektiğini belirtmektedir. Bu maddede, kültürel mirasın sahip olduğu insanlık tarihine dair bilginin önemi vurgulanarak anıtsal eserlerin yanı sıra belge niteliği taşıyan tüm eserlerin koruma kapsamına alınması dile getirilmektedir. Kültür varlıklarının içerdiği bilginin ortaya çıkartılması, topluma ve bilim dünyasına kazandırılması için belgelemeye ve araştırmaya yönelik konuların önemini vurgulayan Özdoğan (2006), “kültür varlığı” tanımının üç ana bileşeni olduğunu ve bunlardan ilki ve en önemlisinin "bilgi” olduğunu dile getirir ve konuyu şöyle açıklar: "Kültür varlıkları geçmişten günümüze nasıl gelindiğini gösteren bilgi bankalarıdır, ... Kültür varlıklarına sahip olmanın getirdiği en önemli sorumluluk, bunların içerdiği bilgiyi ortaya çıkartmak ve böylelikle tüm insanlığın yararına sunmaktır." (Özdoğan, 2006). Kültür mirasının değerinin öncelikli temel ve objektif belirleyicisi kendisini ortaya çıkaran zaman ve süreçlere ilişkin barındırdığı bilgi miktarı ve bilginin niteliğidir. Kültür mirasının anlam, estetik, nadirlik v.b. özelliklerinin tümü aslında kültür mirasının özgün durumu ve varlığında içsel olarak yer alan kendisine ilişkin bilginin niteliğidir. Kültür mirasının içerdiği bilginin mutlaka korunması gerekliliği ve tarihi bilgi bankalarının çevresiyle bir bütün olarak koruma altına alınmasının anlayışı, Venedik Tüzüğünün bir devamı olarak 1975 Amsterdam Bildirgesi ve 1976 Nairobi Tarihi Alanların Korunması ve Çağdaş Rolleri Konusunda Tavsiye Kararları'nda ve Nara Özgünlük Belgesi'nde ayrıntılandırılmıştır. Nairobi Tavsiye kararlarında, "tarihi miras alanları ve çevreleri yerine konulamaz evrensel mirası oluşturan değerler olarak ele almakta ve her tarihi alan ve çevresi, özel karakterleri ve dengesi onu oluşturan parçaların birbiriyle kaynaşmasına bağlı olan yapılar, mekânsal organizasyon ve çevresi kadar insan faaliyetlerini de içeren bir bütün olarak görülmesi gerektiğini dile getirmektedir" (Ahunbay, 2017). Nairobi tavsiye kararları tekil miras ögesinin sanatsal veya anıtsal değerinin ötesinde bütüncül tutarlı bir miras sistemi olarak görme gereğini vurguladığından önemli bir atılım olarak değerlendirilmektedir (Bandarin, 2019). 1987 Washington Tüzüğü, bütüncül koruma anlayışının bir devamıdır ve koruma, bakım ve onarım dışında tarihi kentlerin geliştirilmeleri ve çağdaş yaşama katılmaları için uygulama araçlarını kapsaması gerektiğini belirtir. Ayrıca Koruma planlarının tarihi kent bölgeleri ile bütün kent arasında uyumun sağlanması gerekliliğini vurgular (Ahunbay, 2017). 1990 ICOMOS Arkeolojik Mirasın Korunması ve Yönetimi Tüzüğü, arkeolojik mirasın hassas ve yenilenemeyen bir kültürel kaynak olduğunu vurgular. Arkeolojik mirasın korunması için arazi kullanım kararlarının denetlenmesi gerekliliğini ve koruma için ilgili politikaların, gelişme ve planlama kadar kültürel, çevresel ve eğitim politikalarıyla da desteklenmesini dile getirir. Arkeolojik mirasın korunmasında uluslararası, ulusal, bölgesel ve yerel düzeydeki planlama politikalarıyla bütünleştirilmesinin önemi belirtilmektedir (ICOMOS, 1990). Ülkemizde henüz bu yönde yasal bir düzenleme yoktur. Fakat gerekliliği çok açıktır.

1992 Malta-Valetta'da imzalanan “Arkeolojik Mirasın Korunmasına İlişkin Avrupa Sözleşmesi, kültür mirası ile ilgili olarak ortaya çıkan yeni oluşum, tanım ve kavramları yansıtır ve 21 . yüzyılın başlarına damgasını vuracak olan yaklaşımların ipuçlarını verir (Özdoğan,2006). Arkeolojik miras, insanlığın ortak mirası olarak değerlendirilmekte ve arkeolojik mirası koruma sorumluluğunun yalnızca doğrudan ilgili devlete ait olmadığının, bozulma tehlikesinin azaltılması ve uzman ve deneyim değişimi suretiyle korumanın gerçekleştirilmesi bakımından sorumluluğun Avrupa ülkelerinin tümüne ait bulunduğunun altı çizilmektedir (TBMM, 1999). 1970’lerden itibaren özellikle UNESCO'nun girişimleriyle ortaya konan “Dünya Kültür ve Doğal Mirası" kavramıyla arkeolojik mirasın korunmasında da tüm insanlığın ortak sorumluluğu olduğu anlayışı yerleşmeye başlamıştır. 1999 yılında ülkemizde de kabul edilen 
Valetta sözleşmesi, arkeolojik mirasın tanımı, miras kimliğinin saptanması ve koruma önlemleri, bilimsel bilginin toplanması ve yayılması, kamuoyunun bilinçlendirilmesi gibi birçok konuya değinmektedir (TBMM, 1999). Yeni kavram ve bakış açılarında arkeoloji bilim dalının kapsamı genişlemiş, insanlığı bugüne taşıyan ortak değerlerin göstergesi olmak ve bu bileşimi oluşturan yerel kimliklerin korunmasını sağlama hedefleri yanı sıra, arkeolojik mirastan sadece uzman değil tüm toplumun yararlanması gerektiği ortaya konulmuştur (Özdoğan, 2006).

2000'li yıllarda Budapeşte Deklarasyonu ile koruma sürecinde güvenirlik, kapasite geliştirme ve iletişim gibi kavramların önemine işaret edilirken, Faro Sözleşmesi ise, korumanın kapsamını kültürel çeşitliliği içerecek şekilde genişletmiştir (Dinçer, 2013). Faro Sözleşmesi, kültürel mirasın toplumla ilişkisine odaklanır. Nesne ve yerlerin tek başına kültürel miras olarak önemli olmadığını ancak insanların onlara atfettikleri anlam, kullanım ve temsil ettikleri değerler ile önem kazandığını dile getirir (Council of Europe, 2005). Faro Sözleşmesi sivil girişim ve toplulukların karar verme kapasitelerini geliştirmelerini ve kalkınma süreçlerini yönetmelerini sağlayarak, mirasın toplulukların sosyal, kültürel ve ekonomik dinamiklerine katkıda bulunmasını teşvik eder (Council of Europe, 2005). Yine 2000'li yılların önemli gelişmelerinden olan 2003 Dünya Mirası ve Çağdaş Mimari Uluslararası Konferansı sonucu olan Viyana Memorandumu ile geleneksel terimler olan "tarihi merkezler", "topluluklar" veya "çevre” terimleri yerine daha geniş içerik ve mekânı kapsayan peyzaj bağlamını içerecek tarihi kentsel peyzaj kavramı açıklanır (UNESCO, 2005). 20I I UNESCO Paris genel konferansında kabul edilen Tarihi Kentsel Peyzaj'a ilişkin tavsiye kararı, kavramı açıklayarak uygulama araçlarını, yönlendirici politikaları, kapasite geliştirme ve iletişim gibi konuları içerir (UNESCO, 20I I). Bu kararda, tarihi kentsel peyzaj, sitin topografyası, jeomorfolojisi, hidrolojisini kapsayan doğal özellikleri, hem tarihi hem de çağdaş yapılı çevreyi, altyapı, açık alanlar ve bahçeleri, arazi kullanım düzeni, algı ve görsel ilişkileri de içeren kentsel dokunun diğer tüm unsurları ile sosyal ve kültürel değerleri, ekonomik süreçleri ve toplumsal çeşitlilik ve kimliği oluşturan somut olmayan mirasın da tüm boyutlarını içine alan geniş bir içerik ile tanımlanır (UNESCO, 20II). Bu geniş tanım kültürel mirasın bu bağlamı içinde nasıl sürdürülebilir olacağını ve olması için iyi bir şekilde organize edilmesi gerekliğini ve araçlarını de belirtmektedir. Kültürel mirasın, Birleşmiş Milletlerin sürdürülebilir kalkınma hedefinin bir parçası haline getirilerek Yeni Kentsel Gündem'e uyarlanması (Habitat III) ile Tarihi Kentsel Peyzaj uygulamasının kentsel koruma politikalarının yeniden şekillendirilmesinde belirleyici olacağı görülmektedir (Fayad ve Bucklet, 2019).

Yukarıda yer alan kültürel mirasın korunmasında kültür, doğal, çağdaş yaşam, yapılı çevre ve somut olmayan kültür ögelerinin hepsinin bir bütün olduğu ve bu bütünün içinde yer alan her bir ögenin birbiri ile ilişkilerinin anlaşılması ve iyi değerlendirilerek bu ilişkiler ile korunup sürdürülebilirliğinin sağlanması ve güncel yaşamın bir parçası haline getirilmesi ifade edilmektedir. Kentler geçmişte olduğu gibi gelecekte de zenginleşmek için değişmeye ve gelişmeye devam edecektir. $\mathrm{Bu}$ durum, geçmişi korunması ve gelecek kentsel ihtiyaçların karşılanması arasında bir denge kurulması gerektiği anlamına gelir (Council of Europe, 2000). Kültürel mirasın korunması artık sadece kendine has karaktere sahip olan bir bölgenin “dondurulması” değil, kentsel alanların kimliklerini güçlendirme ve daha geniş süreçte kentsel kalkınma için model oluşturma imkanı verir (Bandarin, 2019). Bunu sağlamanın yolu ise geçmiş ve geleceği aynı duyarlılıkta gözeten iyi bir planlama ile mümkündür. İyi bir planlamanın yapılabilmesi ise, bu plana esas olacak kültür envanterinin varlığına bağlıdır (Özdoğan, 2006). Hem yerel hem de ülke ölçeğinde bu anlayışın benimsenmesi, yerel ölçekte kentin büyüme ihtiyaçları ile ülke çapında büyük yatırımlar bu kapsamda düşünülerek, bütünsel bir envanter bilgi sistemine bağlı olarak kültür varlıklarının korunması ülke ölçeğinde stratejik plan ile başlamalıdır. Ancak bu bakış açısıyla Özdoğan'ın da (2006) belirtiği gibi; kültürel miras ile çağdaş gelişme, birbirlerinin uzlaşmaz karşıtları haline gelmez, birbirlerini tamamlayarak, zenginleştirirler.

\section{Farklı Dönemlere Ait Kültür İzlerinin Tabakalaştı̆̆ı Yerleşmelerde Planlama Sorunları}

Ülkemizde 2018 sonu itibariyle 17.958 arkeolojik sit alanı tespit edilerek koruma altına alınmıştır. Bunlardan 65 arkeolojik sit alanı, kentsel ve tarihi sit alanlarıyla çakışarak karma sitleri oluşturmakta ayrıca 34 kentsel arkeolojik sit alanı bulunmaktadır. (KTB, 2018). Tam olarak sayısı bilinmemekle birlikte günümüz modern yerleşimleriyle çakışan arkeolojik sit alanlarının sayısı da hayli fazladır. Farklı dönemlere ait kültür izlerinin tabakalaştı̆̆ı yerleşme alanları diğer ifade ile çok katmanlı kentler, yukarıda yer alan sayılardan da anlaşıldığı üzere birbirinden faklı sit alanları olarak tanımlanarak tescillenmişlerdir. Bir kısmı "kentsel sit + arkeolojik sit" alanıyken, bir kısmı "kentsel arkeolojik sit" alanıdır, diğer bir kısmı ise sadece "arkeolojik sit" alanıdır ama günümüz yerleşimiyle çakışmaktadır. Sit alanı farklııklarına bağlı olarak da koruma ve kullanma şartları birbirinden farklılaşmaktadır. Fakat aslında hepsi çok katmanlı kentlerdir. Söz konusu sit alanları, farklı kültür katmanlarının bütüncül olarak korunmasını sağlarken kentle bütünleşmesini içerecek çözüm önerileri sunan koruma planları ve bunlara erişmek için yararlanılacak yasal, yönetimsel araçların güçlendirilmesine intiyaç duyar. Bu noktada yasal sistemdeki, kentsel arkeolojik sit alanı ile arkeolojik sit alanı koruma ve kullanma koşullarını hatırlayarak sorun alanlarına daha ayrıntılı ele almak gerekir.

2863 sayılı Kültür ve Tabiat Varlıklarını Koruma Kanunu, korunması gerekli kültür ve tabiat varlıklarının korunma alanla- 
rının tespiti ve bu alanlar içinde inşaat ve tesisat yapılıp yapılamayacağı konusunda karar alma yetkisini kültür ve tabiat varılıkları koruma bölge kurullarına verir ve sit alanlarına ilişkin uygulamaya yönelik karar almak Koruma Yüksek Kurulunun ilke kararları çerçevesinde gerçekleştirilir (KTB, 1983). Bu kapsamda "Kentsel Arkeolojik Sit Alanı", Kültür ve Tabiat Varlıkları Koruma Yüksek Kurulu 1993 tarihli 338 sayılı ilke kararı ile tanımlanır. Daha sonra değişen bu ilke kararının güncel hali 2005 tarihli 702 sayılı ilke kararıdır ve "Kentsel Arkeolojik Sit Alanları Koruma ve Kullanma Koşulları" nı tanımlar. İlke kararında, “.....Arkeolojik sit alanları ile birlikte korunması gerekli kentsel dokuları içeren ve bu özellikleri ile bütünlük arz eden korumaya yönelik özel planlama gerektiren alanlar kentsel arkeolojik sit alanları" olarak belirtilir. Bu alanlarda arkeolojik değerlerin bilimsel yöntemlerle açığa çıkarılması, onarılması ve sergilenmesi işlemlerinin sağlıklı ve kapsamlı arkeolojik envanter temeline dayalı yapılması gerekliliği ilke kararında ifade edilir. Kentsel Arkeolojik Sit tanımının yasal sistemde yer alması bu alanların korunması, yönetilmesi ve planlamasında var olan sorunlar için önemli bir adımdır. Fakat kentsel arkeolojinin ülkemizde yeni bir kavram olması, arkeoloji disiplin alanına yeni bir bakış açısı sunması ve mimarlık ve kent planlama gibi diğer ilişkili disiplinlerle ortak araştırma ve uygulama ihtiyacı bu alanın yeterli gelişmişlik düzeyine ulaşmasını zorlaştırmaktadır. Illke kararında da yeterli açıklama ve yönlendirici ilkeler yer almamaktadır. Kentsel arkeoloji tanımı bile hala farklı algılamalara sebep olabilmektedir. Kentsel arkeoloji alanının öncülerinden Bart Salwen (Rothschild ve Wall, 2008), kent arkeolojisinin iki farklı şekilde algılandığını belirterek şöyle açıklar; kentteki arkeoloji ve kentin arkeolojisi. Kentlerdeki arkeoloji, günümüz kentlerinde yer alan arkeolojik kazı ve bilimsel araştırma faaliyetleridir. Fakat söz konusu bu faaliyetlerde kentin kuruluşundan günümüze kadar olan gelişiminin nasıl evrildiğinin önemi yoktur. Kendi içinde ilerleyen ve dönemine ışık tutan bir çalışmadır. Kentin arkeolojisi ise bunun aksine yerleşim alanını habitat olanı olarak kentin tarihi süreç içerisinde gelişim ve değişiminin araştırılmasını içerir. Yer'in ilk yerleşim izlerinden günümüze kentleşme sürecini nasıl gelişip, değiştiğini araştırır (Rothschild ve Wall, 2008). Kentsel arkeoloji, kenti bir eser olarak görür (Rothschild ve Wall, 2008). Bu eserin antik dönemden günümüze kadar süregelen yaşam kültürünü, içerdiği bilgiyi ve manevi deneyimlerin bütünsel olarak korunmasını amaçlar. Kalıntıların yerlerinde korunmasıyla kentin geçmişine ışık tutan özel mekanların ortaya çıkmasını sağlar (Ahunbay, 2010). Kent arkeolojisi, kentin herhangi bir yerinde bir yapıyı ortaya çıkartmak, ya da tabakalanma almak için yapılan bir sondaj değil, bütüncül bir planın parçası olarak düşünülmekte ve böylelikle kentteki kültürel varlıkların yaşamı engelleyici olmadan çekiciliği sağlanmaktadır (Özdoğan, 2006). Kentsel arkeolojide yoğun karmaşık kent dokusunun çözümlenmesi yeni yöntem ihtiyacını da beraberinde getirir ve yöntem içeriğinde günümüz bilişim teknolojilerinin yer aldığı kapsamlı bir envanter ve dokümantasyon çalışmasını içerir.
Arkeolojik envanter ve söz konusu bu envanter ile birlikte arkeolojik sitin topografyasının çıkarılması da önemlidir. Kentsel birikimin tüm unsurları tarihi, doğal ve kültürel değerler kapsamlı olarak değerlendirilmelidir. Bu çalışma arkeolog ve plancılarla birlikte yürütülecek bir çalışmadır ve sitin korunması ve planlanmasında bu işbirliğinin gerekliliği uluslararası sözleşmelerde de vurgulanmaktadır.

Kültür ve Tabiat Varlıklarını Koruma Yüksek Kurulu 658 sayılı ilke kararına göre I. derece arkeolojik sit alanları, sadece korumaya yönelik bilimsel çalışmaların yapılacağı, korunacak ve yapılaşma yasağı olan sit alanlarıdır. 2. derece arkeolojik sit alanları, koruma ve kullanma koşulları koruma kurulları tarafından belirlenen ve korumaya yönelik bilimsel çalışmaların yapılacağı, korunacak sit alanlarıdır. Bu alanlarda yeni yapılaşmaya izin verilmemektedir, alan içinde bulunan ve kullanılmakta olan tescilsiz yapıların basit onarımlarının yürürlükteki ilke kararı doğrultusunda yani koruma kurulları izni ile yapılabileceği belirtilmektedir. 3 . derece arkeolojik sit alanları ise koruma kullanma kararları doğrultusunda yeni düzenlemelere izin verilebilecek arkeolojik alanlardır. Müze denetiminde sondaj sonuçlarına ilişkin rapora bağı olarak inşaat yapılabilecek alanlardır. Mevcut bir yerleşmeyle çakışan arkeolojik sit alanları en fazla sorun yaşanan sitlerdir. Diğer bir deyişle gerek arkeolojik araştırma ve kültür mirasının, gerekse yerleşmedeki mevcut yaşamın sürekliliği yani sürdürülebilirliği plan ve uygulama da sağlanamamaktadır. Nitekim söz konusu bu alanlardaki koruma amaçlı imar planlarında genel anlayış, I. ve 2. derece arkeolojik sit alanının tamamının "yapılaşma yasağı olan arkeolojik sit alanı olarak" gösterilerek mevcut yerleşmenin yok sayılması ve bunun sonucu mevcut yerleşme ve buradaki yaşamın sürdürülebilirliğine dair sağlıklı bir karar üretilememesidir. Antik kent ve günümüz yerleşmesinin koruma kapsamında birlikte ele alındığı koruma planları ise genel olarak alışılmadık ve sıradışı görüldüğünden koruma kurullarında uzun süre bekleyerek, yerleşik ve sübjektif koruma anlayışlarından kaynaklanan kararsızlıklar ve ikna çabaları arasında geçen onay süreci büyük zaman kayıplarına sebep olmaktadır. Halbuki hem mevcut yerleşimin hem de arkeolojik ve bilimsel çalışmaların yapılacağı alanların birlikte düşünülerek planlanması mümkündür, mümkün olduğu gelişen günümüz koruma yaklaşımında ve kentsel arkeoloji kavramının içinde yer almaktadır. Günümüz yerleşmeleriyle çakışan arkeolojik sit alanları için yapılan koruma imar planlarında, kültür varlıklarının korunması ve arkeolojik bilimsel çalısmaların devamı önceliğinde ve yeni yapılaşma yasağına bağlı kalarak, mevcut yerleşimin devamı ve var olan yapı stokunun geleceğinin planlanmasına imkân vermelidir. Arkeolojik mirasın korunması ve arkeolojik bilimsel çalışmaların devamı önceliğinde yapılacak iyileştirme ve işlevsel düzenlemeler düşünülmeli, bu değişiklikler bir plan bütünlüğünde ele alınarak değerlendirilmelidir. Aksi takdirde plan yerine çevre düzenleme projeleri veya basit onarımlar ile sorunlara çözüm aranmakta ya da yapılan müdahalelere du- 
yarsız kalınmaktadır. Bu durum bütünsel koruma anlayışı ve bu anlayışa bağlı oluşturulmuş amaç ve hedeflerin uygulanmasına imkân vermemektedir.

Bu yüzden Türkiye'deki mevcut deneyim ve uygulamalar içinde gerek tarihsel kültür mirasının korunması gerekse günümüz yerleşmesi ve yaşamının sürekliliğinin sağlanmasında bir anlamda koruma denkleminin her iki tarafını doğru bir eşitlikle bir araya getirmiş örneklerden bahsetmek mümkün değildir. Kimi uygulamalarda turizm gibi yüksek gelir getirici faaliyetler ve yapılaşma baskısı gibi karşı konulması zor etkiler altında güncel yaşamın ihtiyaç ve gerekleri arkeolojik ve tarihsel kültür mirası karşısında öncelik kazanırken, kimi bazı örneklerde de arkeolojik değerlerden yana kesin tercihler, güncel yerleşme ve yaşamın tasfiyesine neden olmuştur. Oysa, mekânsal planlamada arkeolojinin planlama süreçlerinin önemli bir parçası olduğu anlaşılmalıdır (Savrum Kortanoğlu, 20I4). Zira, Türkiye gibi çok sayıda ve farklı kültür ve dönemlerden fazlasıyla zengin çeşitlilikte kültür mirasına sahip olan bir ülkede bu bir zorunluluktur.

Örneğin, Afrodisias-Geyre deneyiminin başarılı bir arkeolojik araştırma ve restorasyon çalışmasına karşılık kamu kesimi ve gönüllülerin önemli desteğine rağmen aynı ölçüde başarılı olamamış bir koruma örneğini oluşturduğu söylenebilir. Aydın'daki Afrodisias antik kentinde arkeolojik araştırmalar ve kazı çalışmaları için kalıntıların üzerinde bulunan Geyre Köyü istimlak edilerek sit alanı dışına taşınmıştır.' Kuşkusuz, Afrodisias antik kenti ve Geyre Köyü'nün ilişkisi Türkiye'de farklı dönemlere ilişkin aynı mekânı paylaşan kültür mirası değerlerinin korunmasında yöntem ve tercihler açısından üzerinde durulması gereken öğretici bir deneyimdir. Burada antik kentin öngörülen ve beklenen görkemi karşısında arkeolojik mirasın ortaya çıkarılması ve korunması, üzerinde yer alan mevcut köy yerleşmesinin görece daha genç ve benzerlerine daha sık rastlanabilecek olduğu kabul edildiğinden, diğer bir ifadeyle nadirlik değerinin daha az olduğu kabul edilen kültürel miras değerlerine tercih edilmiştir. Afrodisias antik kentinin bugün görülebilen etkileyici ve görkemli kalıntıları karşısında doğru bir karar olarak görülebilir. Ancak, Afrodisias gibi sıra dışı değerdeki bir tekil örnekte kendini haklı çıkarabilecek böyle bir tercih ne ölçüde genelleştirilebilir? Bu soru kritik önemdedir.

Muğla, Milas İlçesi'ne bağlı, Bafa Gölü kıyısındaki Herakleia antik kentinde ise farklı bir uygulama gerçekleşmiştir. 1989 yılında Herakleia antik kenti, arkeolojik sit alanı olarak ilan edilerek Kapıkırı Köyü’ne kesin inşaat yasağı getirilmiştir. He- rakleia antik kentinde sit ilanı ile inşaat faaliyetleri azalmış fakat tamamen durdurulamamıştır. Köy halkının zaman içinde ortaya çıkan ihtiyaçlarının karşılanması veya yeni yerleşim alanı için önerilerin belirlenmesi göz ardı edilemez bir sorun olarak ortaya çıkmıştır. Bu sorun çerçevesinde Kapıkırı köyünün başka bir yere taşınması fikri yerine Kapıkırı Köyü halkının Herakleia antik kentinde yaşamaya devam etmelerine olanak tanıyacak şekilde, bütünsel bir plan yapılması fikri Latmos bölgesinde uzun yıllar arkeolojik araştırmalar yapan Anneliese Peschlow-Bindokat'nın önerileriyle gündeme gelmiştir (Distelrath, 20II). Bindokat (Distelrath, 20II), “Herakleia'nın daha fazla tahribinin önlenmesi ve eski ile yeninin bir arada, uyum içerisinde düzenlenebilmesi için, köyün yeni imar planının oluşturulması, ayrıca geleneksel tarzdaki konutlara ve bölgeye uyan yeni yapılar ile ilgili öneriler üretilmesi gerekliliğini” dile getirir. Benzer koşullara sahip ve benzer sorunları olan diğer antik kentler içinde örnek bir planlama modeli olması amacıyla 20II yılında Albert Distelrath tarafından "Kapıkırı Köyü halkı, antik kenti tahrip etmeden burada yaşamaya nasıl devam edebilir?" sorusu çerçevesinde bütüncül plan modeli çalışması gerçekleştirilir (Distelrath, 20I I). Bu plan çalışması günün şartlarında imar planı için tavsiye niteliğinde hazırlanır. Fakat tavsiye plan bir imar planına dönüşmemiş günümüzde Herakleia antik kenti arkeolojik sit alanı koruma amaçlı imar planı hala yapılmamıştır.

Burhaniye ilçesinin bir mahallesi olan Ören, Burhaniye kent merkezinden kopuk, seyrek yoğunluklu bir günümüz yerleşmesidir ve yazlık konut taleplerinin baskısından sit alanı ilan edildikten sonra kurtulmuş nadir yerlerdendir. Yaşam döngüsü içinde kentsel ihtiyaçları olan bir yerleşim alanıdır. Sit alanı olması bir yandan yapılaşma baskısını engellemiş fakat diğer yandan yerleşme, mekân kalitesini zaman içinde kaybederek, ekonomik olduğu kadar güncel yaşam açısından da kaderine bırakılmıştır. Yerleşim özellikleri ve arkeolojik sit alanı koruma sorunları açısından Geyre ve Kapıkırı köylerine benzemektedir. Bu üç alan da I ve 2 inci derece arkeolojik sit alanında yer alan mevcut bir yerleşmeyi içerir ve ülkemiz için önemli koruma planı çalışmaları örnekleridir.

\section{Ören Mahallesi Adramytteıon Antik Kenti Sit Alanı}

Ören, Türkiye'nin kuzeybatısında, Edremit Körfezi'nin güney kıyısında, Balıkesir İli, Burhaniye İlçe merkezinin yaklaşık 4 km. batısında bir sahil yerleşmesi ve 1960 yılından beri Burhaniye

\footnotetext{
$196 \mathrm{I}$ yılında Kenan Erim başkanlığında kazıların yeniden başlamasıyla, Afrodisias antik kenti üzerinde yer alan Geyre Köyü’nün de taşınması gündeme gelir. Bölgenin depremselliği ve 1955'de Aydın'da Söke-Balat, 1957'de Muğla Köyceğiz ve 1969 Manisa, Alaşehir'de meydana gelen depremlerin etkisi ve yarattığı tahribat yerleşmenin taşınması için güçlü bir neden yaratır ve deprem riski de gerekçe gösterilerek 1960’lı yıllarda köy kısmen ilk olarak antik kent surlarının 600 m batısına taşınır. 1976 yılında antik şehir surlarının bir kilometre kadar çevresi birinci derece arkeolojik sit alanı ilan edilir. Böylece Yeni Geyre Afrodisias kent surlarının doğusunda kurulur. Ancak, taşınma sorunları çözmez. Yeni Geyre'nin bir kısmı yine arkeolojik sit alanı içinde kalır. Yeni Geyre'nin güneydoğu yönünde gelişmesi kararlaştırılır; fakat mülk sahipleri bu alanda arsa fiyatlarını arttırınca yapılaşma antik şehir surlarıyla Yeni Geyre arasına yönelir (Güçer, 2004; 98). Ancak artan yapılaşma baskısı karşısında Belediye I996'da hazırlanan ama Koruma Kurulu tarafından onaylanmayan bir imar planıyla gelişme taleplerine cevap vermeye çalışır (Güçer, 2004; II2). 2002 yılında ilgili Koruma Kurulu tarafından onaylanan koruma amaçlı imar planı ise, temelde 1996 tarihli onaylanmayan planla önemli benzerlikler gösterir.
} 


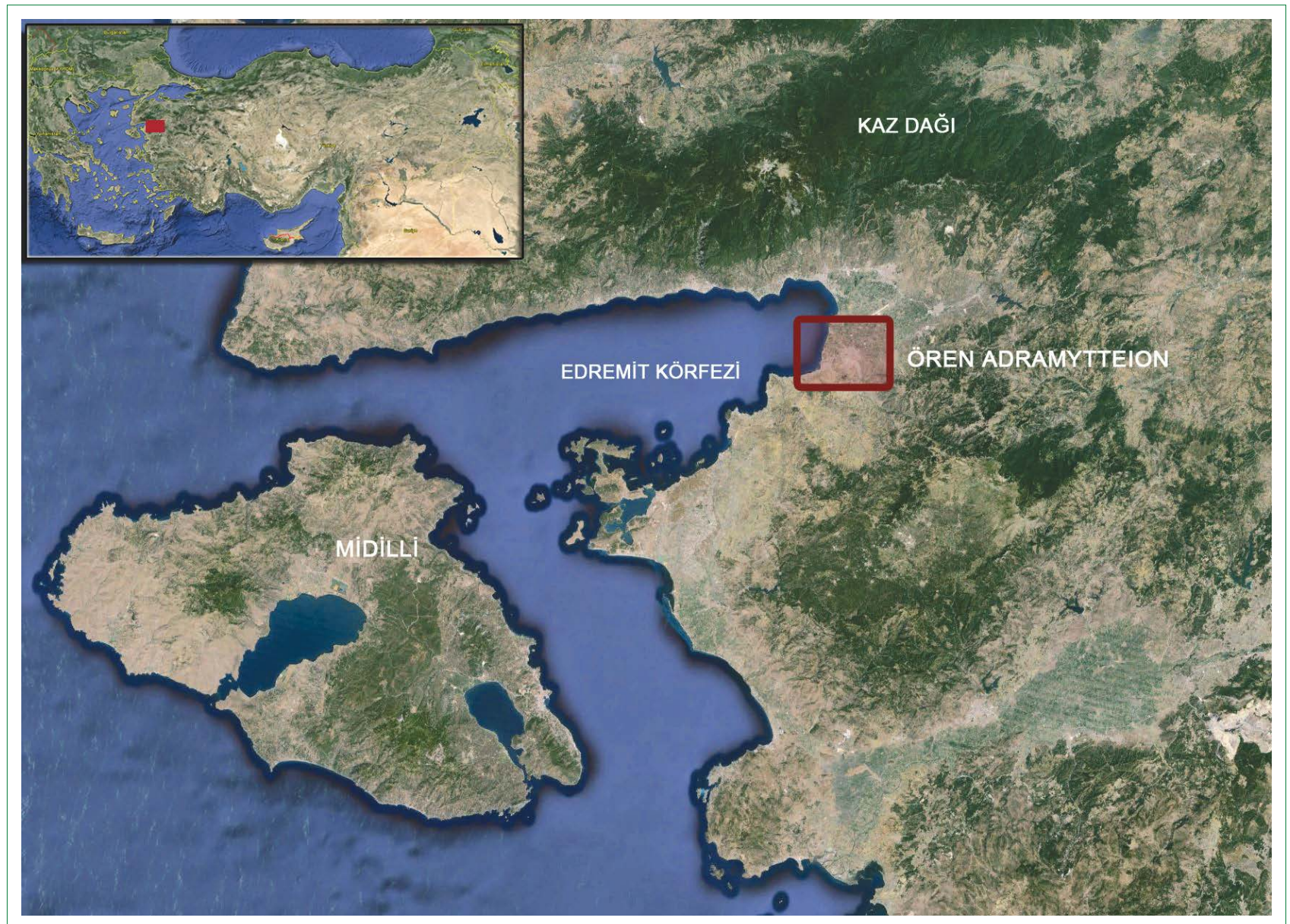

Şekil I. Ören/Adramytteion Antik Kenti'nin konumu.

şehrinin bir mahallesidir (Şekil I). Ören günümüzde çoğunlukla yazlıklardan oluşan bir sayfiye karakterine sahiptir.

Ören'de ve yakın çevresinde 10 m'ye kadar inen delgi sondajlarda elde edilen bulgular günümüzden 6000 yıl kadar önce anakaya üzerine gelen transgresif bir deniz ilerlemesiyle başlayıp, giderek derinleşen bir su ortamına doğru değişimi göstermektedir. Bu sığ deniz ortamı zamanla önce lagün daha sonra tatlı su gölüne dönüşmüştür. Bu tatlı su gölü, zaman içerisinde kuzey ve güneyden gelen taşkın materyalleri ile dolmuş ve bir bataklık halini almıştır. Bu bataklık ortamın, Erken Bizans Dönemi veya sonrasında büyük ölçüde dolmuş olduğu tahmin edilmektedir. Özellikle kuzeydeki Havran Çayı ve güneydeki Karınca Deresi'nin zamanla uzaklaşan yataklarına bağıı olarak alan, bugünkü ova yüzeyine dönüşmüştür. Buna göre, Örentepe, ilk yerleşimlerin başladığı tarih öncesi dönemde ince bir kıstakla anakaraya bağlanan bir yarımada niteliğindedir ve bugünkü Burhaniye şehri ile Ören arasında yer alan düzlük iki bin yıldan daha genç bir oluşumdur (Özgen, 2016; 24).

Adramytteion adına ilk kez ünlü tarihçi Herodotos'un eserinde rastlanmaktadır. Herodotos, Pers Kralı Kserkses'in
Yunanlar’a karşı MÖ 480 yılında yaptığı seferin anlatımında Pers Ordusu'nun Adramytteion kentini geçerek Thebe ovasına (bugün Burhaniye ve Edremit arasındaki ova düzlüğü) indiğinden bahsetmektedir. Ksenephon komutasındaki Yunanlar da M.Ö. 40I'de Adramytteion'un yanından geçerler. Adramytteion'un M.Ö. 4. yy'dan itibaren, özerk bir şehir devleti olduğu, kendi sikkelerini darp ettiği ve bir şehir meclisine sahip olduğu bilinmektedir (Stauber, 1996). Adramytteion, Romalı meşhur hatip Ksenokles'in memleketi olarak da bilinmektedir. Ksenokles, Roma senatosu önünde şehrin ve Asia Eyaleti'nin temsilcisi olarak bölgenin kaderini belirleyecek bir savunma yapmıştır. Zira söylenene göre; Adramytteion halkı, Roma hâkimiyetine olan kinlerinin etkisiyle M.Ö. 88'deki genel bir başkaldırıya katılmıştır. Kent, Roma İmparatorluğu zamanında, bir "conventus" merkezi, yani Asia Eyaleti'nin dokuz mahkeme bölgesinden birinin merkezidir (Çapar, 1995). Roma döneminde Adramytteion'un adı, Apameia, Laodikeia ve Pergamon gibi Anadolu'daki büyük kentlerle birlikte geçmektedir. Adramytteion denize açık konumu ve doğal zenginlikleri sayesinde, çevresinin potansiyelini her daim ticarete yansıtmış bir kent olmuştur. Kaz ve Madra Dağları'ndan elde edilen kereste, bakır ve demir madenleri, kenti özellikle denizcilikte 
ve gemi yapımında da önemli bir konuma getirmiştir. Hatta Yeni Ahit'te anlatıldığı üzere, Aziz Paulus Filistin'den Roma'ya bir Adramytteion gemisiyle seyahat etmiştir. (Özgen, 2013b).

Arkeolojik bulgulara ve yazılı kaynaklara göre, Adramytteion şehri Ortaçağ'da, en geç XIV. yüzyıl başlarında nihai olarak terk edilmiştir. Buradaki nüfus da önceleri muhtemelen Burhaniye yakınlarındaki Taylıeli Köyü, Edremit şehri ve civardaki diğer yerleşmelere dağılmış olmalıdır. Adramytteion şehri terk edilmiş olmasına karşın XIV-XVI. yüzyıl portolan haritalarına ve Piri Reis'in Kitab-ı Bahriye (I525) adlı eserine göre iyi bir demirleme yeri olan ve tatlı su temin edilebilecek sahile yakın bir kaynağın bulunduğu antik limanın mendirek ve rıhtımı bu dönemde hala kullanılabilir durumdadır (Piri Reis, 1988). Piri Reis'in sözünü ettiği tatlı su kaynağı, günümüzde Ören merkezinden kabaca bir kilometre kadar kuzeybatıda yer alan ve doğal sit statüsünde olan Ayaklı Mesiresi'ndeki pınar olmalıdır. XV. yüzyıl başlarına ait Parma-Magliabecchi Portolanı'nda Landermiti isimli bir körfez (Edremit Körfezi) gösterilmiştir (Kretschmer, 1909, 326). Bartolomeo da li Sonetti'nin 1485 tarihli, Venedik'te basılmış olan Isolario adlı eserinde Edremit Körfezi'nde "Landimitri" kenti gösterilmiştir. Her ne kadar haritada kentin konumu Edremit gibi gösterilmiş olsa da, yerleşim kıyıda konumlandırılmıştır. Buradan hareketle Adramytteion'un liman olarak o dönemde halen faal olduğu anlaşılmaktadır (Bartolomeo da li Sonetti, I485, 96). Yine, I490'da Venedik'te basılmış olan Bernardino Rizo da Novaria'nın hazırlamış olduğu portolana göre, Andremiti, Sancta Maria Burnu'ndan (Baba Burnu) önce doğu, sonra da güneydoğu yönünde 40 mil ( 60 km) mesafede kalmaktadır. Buı esere göre, Andremiti bir kent olup iyi bir limanı vardır. Girişi güney ve güneydoğu yönündendir. Limanın dip kısmında irili ufaklı birçok kurumuş porsuk ağacı bulunmaktadır (Kretschmer, 1909, 520).

Adramytteion kenti terk edilmiş olsa da bölgenin denizci kimliği ve gemi inşa geleneğinin Osmanlı döneminde de devam ettiği görülmektedir. Ancak, yerleşmenin ağırlığı daha güneye bugünkü İskele Mahallesi'nin olduğu yere kaymıştır. XVI. ve XVII. yüzyıllarda İskele civarındaki tersanelerde Osmanlı donanması için gemiler inşa edilmektedir (Bostan, 1992, II3II4). Yörenin denizcilik geleneği XIX. yüzyılda sona ermiş görünse de İskele mevki bir ticaret ve ikmal iskelesi olarak varlığını sürdürür. XIX. yüzyılda bugünkü İskele Mahallesi’nin olduğu yerde kurulan gümrük, iskelenin dış ticarette de önem kazandığını göstermektedir. XIX. yüzyıl sonlarında antik Adramytteion yerel halk tarafından ören yeri olarak bilinmektedir. 1894'de yöreden geçen bir Osmanlı hükümet Tabibi Şerafeddin Mağmumi, Adramytteion harabelerini şöyle anlatır: “...Sonra yarım saat kuzeye giderek deniz kenarında ve üç tepeden ibaret ve yerli halkın "yapı" dedikleri eski Edremit kenti harabesini gezdik. Kale bedeni gibi duvarlara, çok büyük küplere, çanak çömlek kırıntılarına bakılınca o zamanlar denizin daha içerilere kadar uzandığı ve daha sonra sellerin, çayla- rın dağlardan indirdiği çöküntülerle yerin dolarak denizin çekildiği anlaşılıyordu. Harabe arazisi ahalinin mülkiyetinde olup, bir çok palamut ağacı yetiştirilmiş ve gereğinde inşaat için de taşları götürülmüştür. Bu kadar kazı yapıldığı halde yazılı bir taş ve değerli madde çıkmamıştır." (Mağmumi, 2008, I36).

Arkeolojik bulgulara ve yazılı kaynaklara göre, Adramytteion şehri Ortaçağ'da, en geç XIV. yüzyıl başlarında nihai olarak terk edilmiştir. Buradaki nüfus da önceleri muhtemelen Burhaniye yakınlarındaki Taylıeli Köyü, Edremit şehri ve civardaki diğer yerleşmelere dağılmış olmalıdır. Ören'de 200।, yılında Engin Beksaç, 2003-2006 arasında Tülin Çoruhlu tarafından Geç Antik Çağ odağında yürütülen (Özgen, 20I3b) ve 2012 yılından bu yana Mimar Sinan Güzel Sanatlar Üniversitesi Arkeoloji Bölümü'nden H. Murat Özgen bilimsel danışmanlığında gerçekleştirilen arkeolojik kazı ve araştırmalarda yerleşmenin içinde çeşitli yerlere dağılmış dört açma ve 58 sondajda Adramytteion antik kentine dair Kalkolitik dönemden XIV. yüzyıl başlarına kadar oldukça kesintisiz şekilde devam eden kültür katmanları tespit edilmiş ve Adramytteion antik kentinin farklı dönemlerine ait çok sayıda buluntu ve mimari eserler ortaya çıkarılmıştır. Bu çerçevede Ören Tepe'nin kuzeyinde yer alan ve tarih öncesi dönemde denize doğru uzanan kayalık bir yarımada olduğu anlaşılan ve halihazırda üzerinde iskan bulunmayan Bergaztepe üzerinde Kalkolitik Dönem'den Geç Antik Çağ’a uzanan kesintisiz kültür katmanları tespit edilmiştir (Özgen, 20I3b). Arkeolojik kazılarda A Bölgesi olarak tanımlanan Ören Meydanı'nda gerçekleştirilen kazıda ise, keramik buluntularla kabaca Orta-Geç Bizans Dönemi'nde (7-12. Yy) kullanım gördüğü anlaşılan çok evreli bir depo yapısı ortaya çıkarılmıştır (Şekil 2) (Özgen, 20।3b). Sit alanı içinde yer alan ve mevcut inşai özellikleriyle M.Ö. 4. yüzyıla tarihlenen Adramytteion antik kentine ait antik liman mendireği de Ören kumsalının hemen açığında belirgin şekilde görülebilmektedir (Özgen, 20I3b). Yazılı kaynaklar mendireğin I5. yüzyılda da kullanım gördüğüne işret etmektedir (Şekil 2). Ören yerleşmesi içinde oldukça merkezi bir diğer konumda yer alan ve D Bölgesi olarak adlandırılan alanda en geç M.S. 12.- 13. yy.larda kullanım gören mekânlara ait çok evreli bir mimari açığa çıkarılmıştır. Büyük oranda mutfak ve sofra kapları buluntuları D bölgesindeki mekânların işlevlerinin günlük hayata ilişkin olabileceğini göstermektedir (Şekil 3) (Özgen, 20I4). M.S. I2-I3. yy.'lara tarihlendirilen Ortaçağ tabakasının altından daha erken dönem mimarisine ait, farklı yöneliş gösteren duvarlarla erken dönem bir Bizans yapısı izine ulaşılmıştır (Özgen, 20।4). Ören Meydanı'na yakın bir noktada sel afetzedeleri için 1950'lerin sonlarında inşa edilmiş olan halen Burhaniye Belediyesi'nin mülkiyetindeki Seylap Evleri'nden iki tanesinin arka bahçesinde açığa çıkarılan yapı izlerinin yer aldığı E Bölgesi'nde de çok evreli bir yapıya ulaşılmıştır (Şekil 3). Kısmen temeline kadar açığa çıkarılmış durumdaki yapı, batıda, liman yönüne bakan bir girişe sahiptir (Özgen, 20l4). Yapının tonozlu girişinin ardında mozaik tabanlı bir avlu ile güneyinde bağlantılı bir mekân 


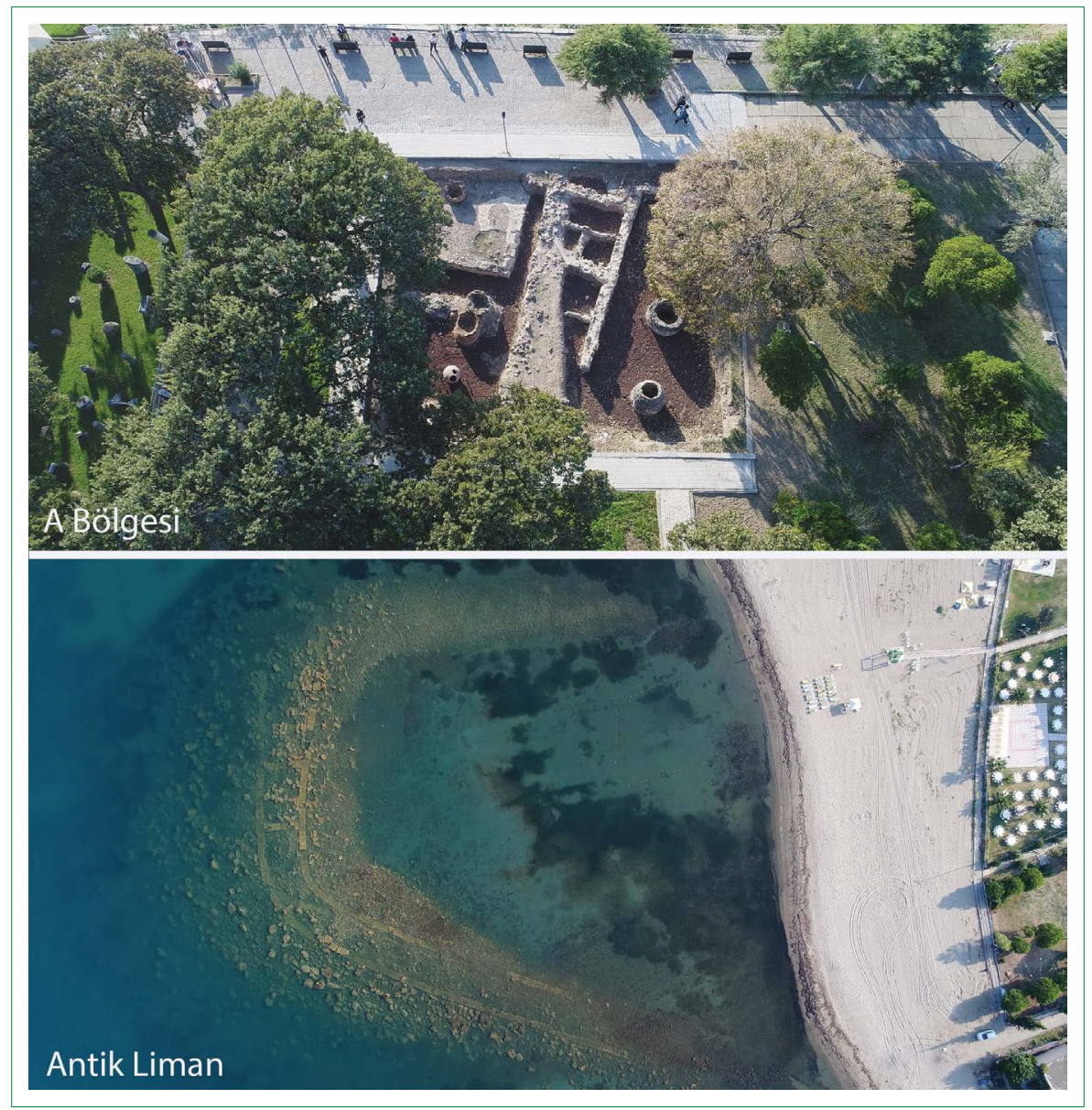

Şekil 2. Ören/Adramytteion Antik Kenti A bölgesi kazı alanı ve antik liman B bölgesi (Kaynak: H. Murat Özgen, 2019.).

kısmen açığa çıkarılmıştır (Özgen, 20।4). Alanda üst kotlarda Erken Bizans Dönemi malzemenin yoğunluk kazanması kronolojik olarak alanın kullanımında $D$ bölgesi ile benzerlikler olduğunu göstermektedir. (Özgen, 20I4). “E Yapısı” M.S. 2. ya da 3. Yy Roma Dönemi'nde olasılıkla hamam olan nitelikli bir kamu yapısına dair somut veriler sunmaktadır (Özgen, 20l8).

2000-2006 arasında Geç Antik Çağ ve Bizans Dönemi odağında sürdürülen kazı çalışmalarının gerçekleştirildiği ve son evresi M.S. 12-13. yy'a tarihlenen bir kilise, Erken Bizans Dönemi'nde kullanılmış bir seramik fırını ve Geç Antik Dönem mezarlarının tespit edildiği ve Adramytteion antik kentinin başlıca yükseltilerinden birini oluşturan, Adramytteion Kazı Evi'nin de yer aldığı arazi içindeki kazı alanı, yeni dönem kazılarında "C Bölgesi” olarak adlandırılmıştır. ${ }^{2}$ Yeni dönem kazılarında bu bölgede apsisli bir duvar ile karşılaşılmıştır. Böylelikle, Erken ila Orta Bizans Dönemi'ne ait yeni bir kilise yapısı tespit edilip, çalışmalar kapsamında "Kuzey Kilise" olarak adlandırılmıştır. Büyük apsisin M.S. 8. yy.da inşa edildiği ve M.S.
II. yy'da tadilat geçirdiği görülmüştür. Yapı, daraltılmış apsisle mezar şapel niteliği kazandırılarak yeniden düzenlenmiştir. Yapının pişmiş toprak zemini altına uzun süre gömü yapıldığı görülmüştür. Alan geneliyle birlikte düşünüldüğünde, tespiti yeni yapılan erken kilisenin bir tahrip veya yıkım nedeniyle M.S. I I. yy'da mezar şapeli olarak daraltılıp düzenlendiği, devamında ise kazısı 2000'li yıllarda yapılan kilisenin kullanıma girdiği anlaşılmaktadır. M.S. II yy'ın, Bizans Dönemi Adramytteion'u için önemi göz önüne alındığında bu durum Adramytteion için son bir nefes olan M.S. 12 ila 13. yy’lardaki yoğun iskânının bir diğer kanıtı olarak yorumlanmıştır (Özgen, 20I8).

Adramytteion (Ören) Antik Çağ'da önemli bir kentsel merkez olduktan sonra bir anlamda uzunca süren bir dinlenme dönemine girmiştir. Bu uzun uykudan gözlerini açması ve yeniden bir yerleşmeye dönüşmesi ise 20. yüzyılın ikinci yarısında gerçekleşecektir. Ören ve çevresi seyrek dokulu bir kırsal yerleşme iken, 1950’lerde deniz kıyısındaki palamut meşesi ağaçlarıyla kaplı tepe üzerinde bir iskan girişimi başlamış ve

2 Bu bölgede 2000-2006 yılları arasında yapılan çalışmalar içi bkz. : Beksaç 2003, 85-94; Beksaç 2004, 327-338; Çoruhlu 2006, 229-240; Çoruhlu 2007, 479-500; Çoruhlu 2008, 525-540. 


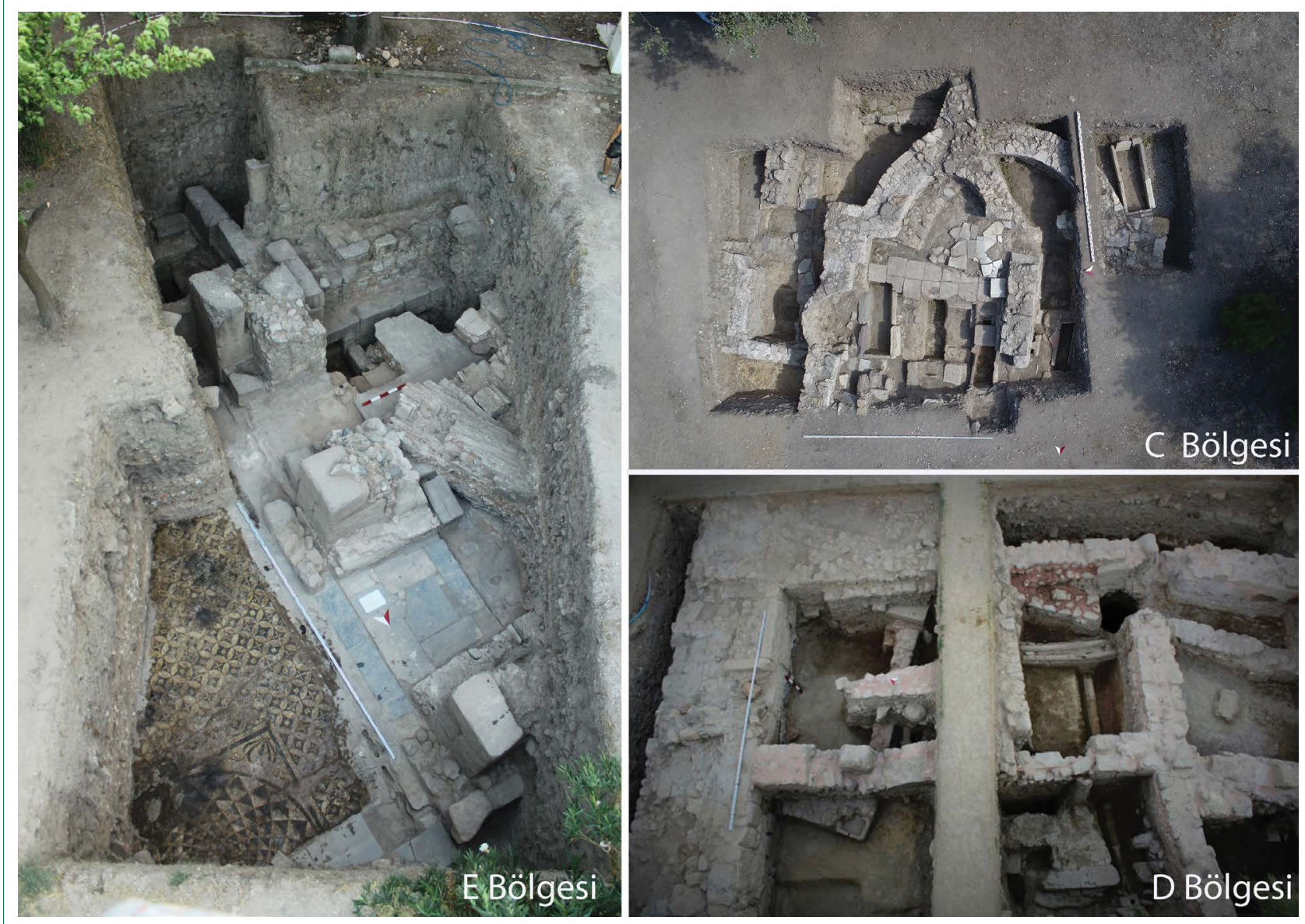

Şekil 3. Ören/Adramytteion Antik Kenti C, D ve E bölgesi kazı alanı (Kaynak: H. Murat Özgen, 2019.).

çoğunlukla bahçeli sayfiye evlerinden oluşan düşük yoğunluklu bir yazlık yerleşme ortaya çıkmıştır. Bugünkü Ören yerleşmesi 1954-1960 yılları arasında Burhaniye'de kaymakamlık yapan Hüseyin Öğütçen öncülüğünde 1955-1960 arasında Burhaniye Belediye Başkanlığı yapmış olan Avni Meço işbirliği ile ortaya çıkmış ve biçimlenmiştir (2. Yazar, 20I3a).

\section{Arkeolojik Sit Alanı Koruma Kapsamı}

Kırsal ve kentsel sitlerin korunmasıyla ilgili kararların alınması 1964 Venedik Tüzüğü ile gerçekleşmiş, sadece anıtın korunması değil çevresinin de korunmasına dair yasalar geliştirilmiştir. Venedik Tüzüğü ülkemizde o dönem koruma uygulamalarını yönlendiren bilimsel kuruluş Gayrimenkul Eski Eserler ve Anıtlar Yüksek Kurulu tarafından benimsenmekle birlikte, ilkelerini hemen ve tam olarak uygulamaya koymak mümkün olmamıştır (Ahunbay, 2017). Tarihi kentlerdeki kültür varlıkları bu dönemde ancak tek tek tescil edilerek koruma altına alınmıştır (Ahunbay, 20 I7). 1973 Temmuz ayında koruma açısından önemli bir yenilik ve aşama olan "sit" kavramını getiren I7I0 sayılı Eski Eserler Kanunu'nun yasalaşması ile korunması gerekli "eser” kavramı tek yapı ölçeğinin dışına çıkmış, yapıla- rın bir araya gelerek oluşturdukları arazi parçalarını da koruma konusu olduğu benimsenmiştir (Madran, 1987). Adramytteion antik kentinin yerleşime açılması da 1710 sayılı Eski Eserler Kanunu'ndan önce 1958 ile 1960 yılları arasında henüz sit ilan edilmediği dönemde gerçekleşmiş, Adramytteion şehrine ait izler tahrip olmuş ve antik şehir, mevcut yerleşmenin altında kalmıştır. Dönemin bakış açısını ortaya koyan Özdoğan'nın (2006) sözleri şöyledir; “1970’li yıllarda hiçbir yerel yönetim kendi bölgesindeki kültür varlığını ön plana çıkartmayı düşünmezdi; düşünmek bir yana, onlardan kurtulmak isterdi. Yine 1970'li yıllarda, ne kadar ön plana çıkartıp vurgulamaya çalışsak da en önemli kültür varlığının tahribi bile toplumda duyarlıık uyandıramamaktaydı”. Söz konusu bu anlayış, Adramytteion antik kentinde bir yerleşim alanı projesi için yasal ve toplumsal bir destek sağlamış ve arkeolojik mirasın bir kısmının geri döndürülemez düzeyde zarar görmesine sebep olmuştur. Ören ve çevresinde yapılaşma başlamadan önce yüzeyde görülen ve inşaatlar sırasında bulunan çeşitli tarihi eserler toplanarak bugün Ören Meydanı'nda açık hava sergisi şeklinde teşhir edilmektedir. Yöre halkı ve dönemin belediye çalışanlarından alınan bilgilerde eserlerin hepsinin sergilenemediği bir kısmının da tahrip edildiği dile getirilmektedir. 


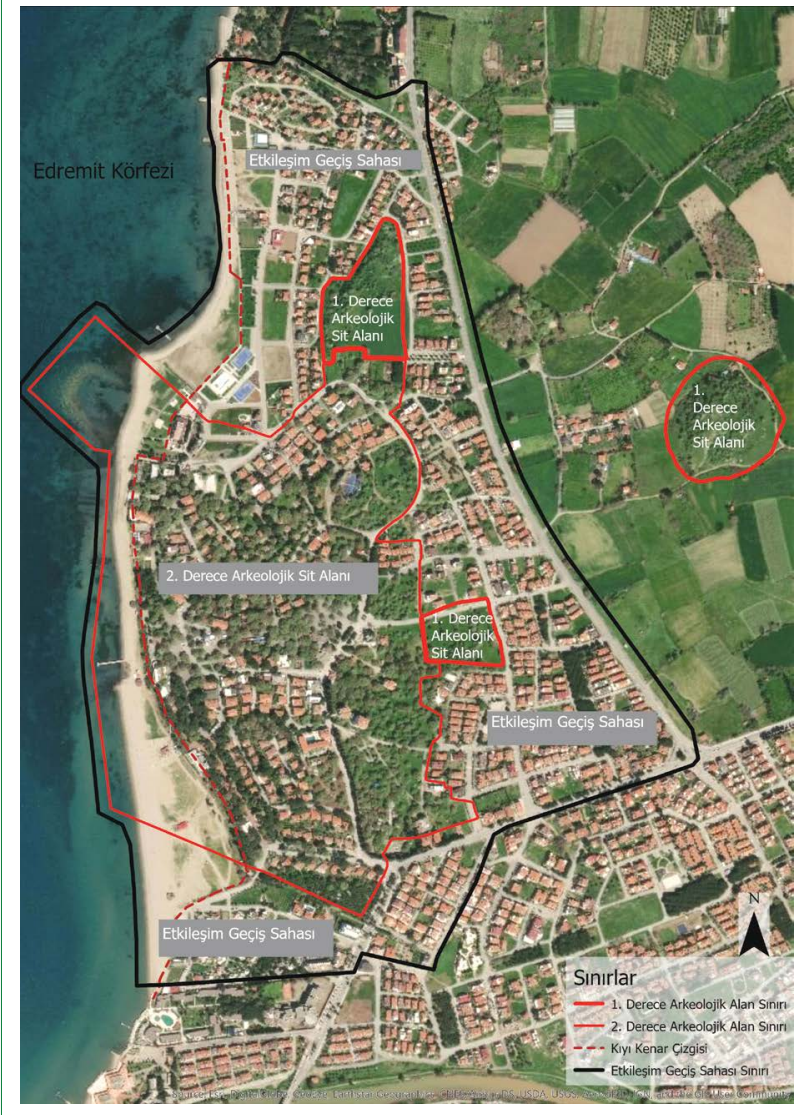

Şekil 4. Ören/Adramytteion Antik Kenti I. ve 2. Derece Arkeolojik Sit Alanı ve etkileşim geçiş sahası sınırları.

Ayrıca 1960'ların başlarında da Ören sakinleri tarafından bu eserlerin toplanarak yörede bir müze talebinde bulunulduğu ve dönemin mülki amirlerinin de yörede bulunan arkeolojik eserlerin sergileneceği bir müze kurulması konusunda vaatte bulundukları döneme ait gazete haberlerinden izlenebilmektedir. $^{3}$ I 973 tarihli 1710 sayllı Eski Eserler Kanunu'nun kabul edilmesinden iki yıl sonra 1975 yılında Ören Adramytteion antik kenti sit alanı olarak tescillenmiştir. Bu karar kapsamında Ören'de oluşturulan Tarihsel Sit Alanı bugünkü Arkeolojik Sit Alanı'ndan daha geniş şekilde, kabaca Ören Adramytteion Arkeolojik Sit Alanı Koruma Amaçlı İmar Planı onama sınırlarına yakın bir alanı kapsamaktadır. 1983 yılında 2863 sayılı Kültür ve Tabiat Varlıklarını Koruma Kanunu'nun yürürlüğe girmesini izleyen yıllarda sit alanının tekrar gündeme geldiği ve sit sınırlarının değiş̧irildiği görülmektedir. Adramytteion yerleşme alanı Bursa Kültür ve Tabiat Varlıkları Koruma Kurulu'nun
Tablo I. Ören, Adramytteion Arkeolojik alanlarının yüzölçümleri

\begin{tabular}{lc} 
I. derece arkeolojik sit alanı & 7.19 ha. \\
2. derece arkeolojik sit alanı & 39.02 ha. \\
Toplam arkeolojik sit alanı & $46.2 \mathrm{lha}$. \\
Etkilenme/geçiş bölgesi & $61.24 \mathrm{ha}$. \\
Toplam planlama alanı & 107.45 ha. \\
\hline
\end{tabular}

Kaynak: 2. Yazar, 2013b: 57.

1989 ve 1990 yıllarındaki kararlarıyla 2. ve I. derece "arkeolojik sit alanı" ilan edilmiştir (Şekil 4).

Adramytteion antik kentinin sit ilanından sonra alanda yeni yerleşim alanları açılmamış mevcut yerleşim, çevresinde yer alan yazlık konut talebine karşı kendini koruyabilmiş ve sit alanı geçiş dönemi ilkeleri uygulanmıştır. Hiç kuşkusuz ki bir antik kentin yerleşime açılmış olması kabul edilemez ve tüm dönemler için yanlış bir karardır. Sit alanı ilan edildikten sonra korunması ve tahribatın durması ise aynı ölçüde olumlu bir durumdur. Bugün karşı karşıya kalınan durum ise arkeolojik miras ile 20. yüzyıl yerleşim alanın üst üste çakıştığı bir yaşam alanıdır ve arkeolojik mirasın korunması, arkeolojik bilginin ortaya çıkarıması, toplum ile paylaşılması yapısal ve doğal çevre ile korunan değerlerin bütünleştirilmesi gerekliliği de çok açık bir şekilde görülmektedir. Bu kentsel yaşam alanında koruma amaçlı imar planının yapılması bu açıdan büyük önem arz etmektedir.

Ören/Adramytteion I. ve 2. derece arkeolojik sit alanları 46,2 hektardır ve sit alanlarının çevresinde 6I,2 hektar etkileşim-geçiş sahası tanımlanmıştır (Tablo I, Şekil 4). 1990 sit kararları ardından sit alanında imar hakları dondurulmuş ve bu alanda her ölçekteki plân geçerliliğini yitirmiştir. 2863 sayılı Kültür ve Tabiat Varlıklarını Koruma Kanunu uyarınca sit alanlarında, alanın etkileşim-geçiş sahasını da göz önünde bulundurarak, kültür ve tabiat varlıklarının sürdürülebilirlik ilkesi doğrultusunda korunması amacıyla koruma amaçlı imar planı yapılması gerekli kılınmıştır. 1990 yılından 2012 yılına kadar bu bölge için koruma amaçı̆ı imar planı yapılmamış geçiş dönemi koruma esasları geçerliliğini sürdürmüştür. 2012 yılında $\mathrm{H}$. Murat Özgen danışmanlığında kazı çalışmalarının başlamasıyla koruma amaçlı imar planı yapımı gündeme gelmiş ve plan çalışmalarının kazı ekibi danışmanlığında yapılmasına karar verilmiştir. Ören/Adramytteion Arkeolojik Sit Alanı Koruma Amaçlı Plan ekibi ${ }^{4}$ ve arkeolojik araştırma eki-

\footnotetext{
3 Ören'de yapılaşmanın başladığı ilk yıllarda yerel basında yöre halkının Ören'de arkeolojik eserler için bir müze talebinde bulunduğu ve çevreden toplanan çeşitli eserlerin o dönemlerde geçici olarak Burhaniye'de bir eczane vitrininde sergilendiğine dair haberler yerel basında yer alır. Bu istek ve taleplere karşı o yıllarda Kaymakamlık tarafından da Ören'de bir müze kurulması sözü verilir. Bu konuda dönemin Kaymakamı yerel gazetede “müzenin müsveddesinin tesis edildiğini, önce çıkartılan eserlerin toplanmas gerektiğini, vatandaşların bir kısmının bu tarihi eşyaları Belediye'ye teslim ettiklerini ve bunların Çakıroğlu Eczanesi vitrininde teşhir edildiğini bildirerek, ellerinde bu türden eşya bulunanlardan makbuz karşılığı eserlerin Belediye'ye teslim edilmesini” ister (Burhaniye Devrim gazetesi, 18, 19 Ekim 1962).

4 Koruma Amaçli İmar Planlari ve Çevre Düzenleme Projelerinin Hazirlanmasi, Gösterimi, Uygulamasi, Denetimi ve Müelliflerine İlişkin Usul ve Esaslara Ait Yönetmelik'in 17. Maddesine göre, koruma amaçlı imar planlarının müellifi, şehir plancısı veya şehir ve bölge plancısı veya kent plancısıdır. Planlama ekibinde alanın konumu, sit statüsü ve özellikleri göz önünde bulundurularak mimar, restorasyon konusunda yüksek lisans yapmış mimar, sanat tarihçisi, arkeolog, sosyolog, mühendis, peyzaj mimarı gibi meslek gruplarından yeterli sayıda uzman görev alır. Adramytteion Arkeolojik Sit Alanı Koruma Amaçılı İmar Planı, Plan ekibinde şehir plancısı (5 kişi ), mimar (I kişi), restorasyon konusunda yüksek lisans yapmış mimar (3 kişi), arkeolog (3 kişi) ve sosyolog (I kişi) görev almıştır.
} 


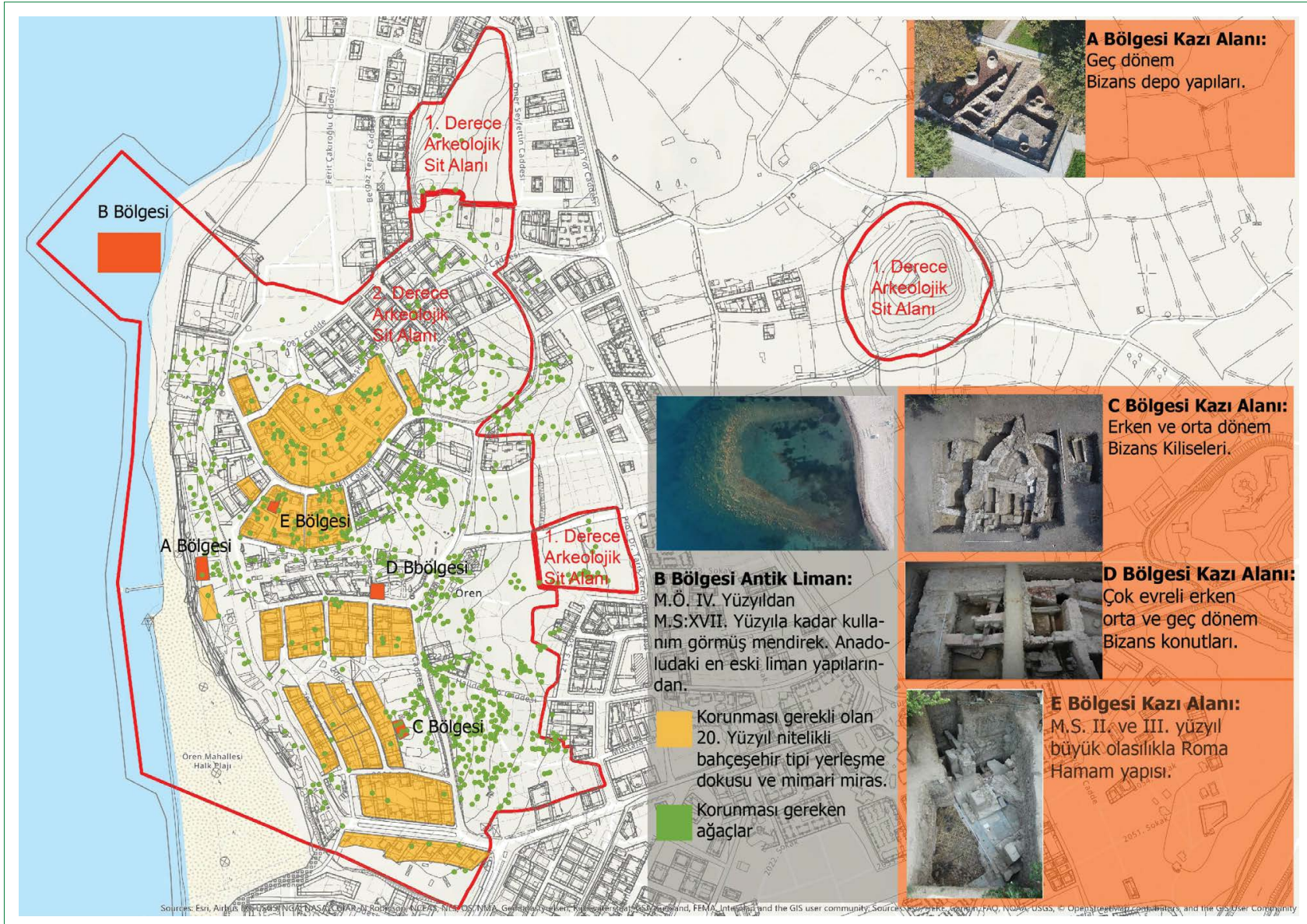

Şekil 5. Ören/Adramytteion Antik Kenti Arkeolojik Sit Alanı korunması gerekli miras ögelerinin harita üzerinde gösterimi.

binin birlikte çalışma imkanı makalenin temel sorusu olan korunması gerekli doğal ve kültür mirasının kapsam ve koruma yöntemi üzerinde birlikte karar vermeyi sağlamış ve uzun soluklu bir çalışma yürütülmüştür.

Ören/Adramytteion Koruma Amaçlı İmar Planı'nda bilgi temelli bir koruma anlayışı benimsenmiştir. Miras değerlerinin korunmasının temel varlık nedeni bilginin korunması olmalıdır. Bilginin korunması ise, ancak tam anlamıyla bilginin ait olduğu, o bilginin taşıyıcısı olan nesnenin korunması ile mümkündür. Herhangi bir nesnenin resim, fotoğraf, çizim, anlatım gibi farklı ortamlardaki temsilleri hiçbir zaman nesnenin varlığının bir parçası olan, özünde yer alan bilgiyi tam olarak taşıyamaz, aktaramaz. Bundan dolayı, nesne özgün varlığıyla korunduğu oranda, nesneye ait bilgi de korunmuş olacaktır. Bir diğer unsur ise, kültür mirasının bir parçası olarak bulunduğu doğal ve yapılı çevre ögeleri yani bir anlamda arkeolojik sitin güncel topografyası incelenerek korunacak değerler çevresiyle bütünsel ilişkisi içinde değerlendirilmiştir. Koruma amaçlı imar planı amaç ve kararlarını aşağıda maddeler halinde sıralanan uluslararası sözleşme ve tüzük ilkeleri yönlendirmiştir.

\section{Venedik Tüzüğü;}

- “Tarihi anıt kavramı sadece bir mimari eseri içine almaz, bunun yanında belli bir uygarlığın, önemli bir gelişmenin, tarihi bir olayın tanıklığını yapan kentsel ya da kırsal bir yerleşmeyi de kapsar." (Venedik Tüzüğü, 1964).

Nairobi Tavsiyeleri;

- "Her tarihi alan ve çevresi, özel karakteri ve dengesi, onu oluşturan parçaların birbiriyle kaynaşmasına bağı olan ve yapılar, mekânsal organizasyon ve çevresi kadar, insan faaliyetlerini de içeren tutarlı bir bütün olarak görülmelidir." (UNESCO, 1976).

Valetta Arkeolojik Mirasın Korunmasına İlişkin Avrupa Sözleşmesi;

- “Korunması ve incelenmesinin, insanlığın ve doğal çevre ile ilişkilerinin tarihindeki gelişimin saptanmasının sağlayacağı;

- Başlıca bilgi edinme yollarının kazı ve keşiflerden olduğu kadar insanlığı ve çevresini ilgilendiren diğer araştırma yöntemlerinden oluştuğu;

- Tarafların yetkisi altındaki her çeşit mekânda bulunan, tüm kalıntılar, varlıklar ve insanlığın geçmiş varlığının diğer izleri arkeolojik mirasın ögeleri kabul edilirler.

- Yapılar, inşaatlar, mimarî eser grupları, açılmış sit alanları, 

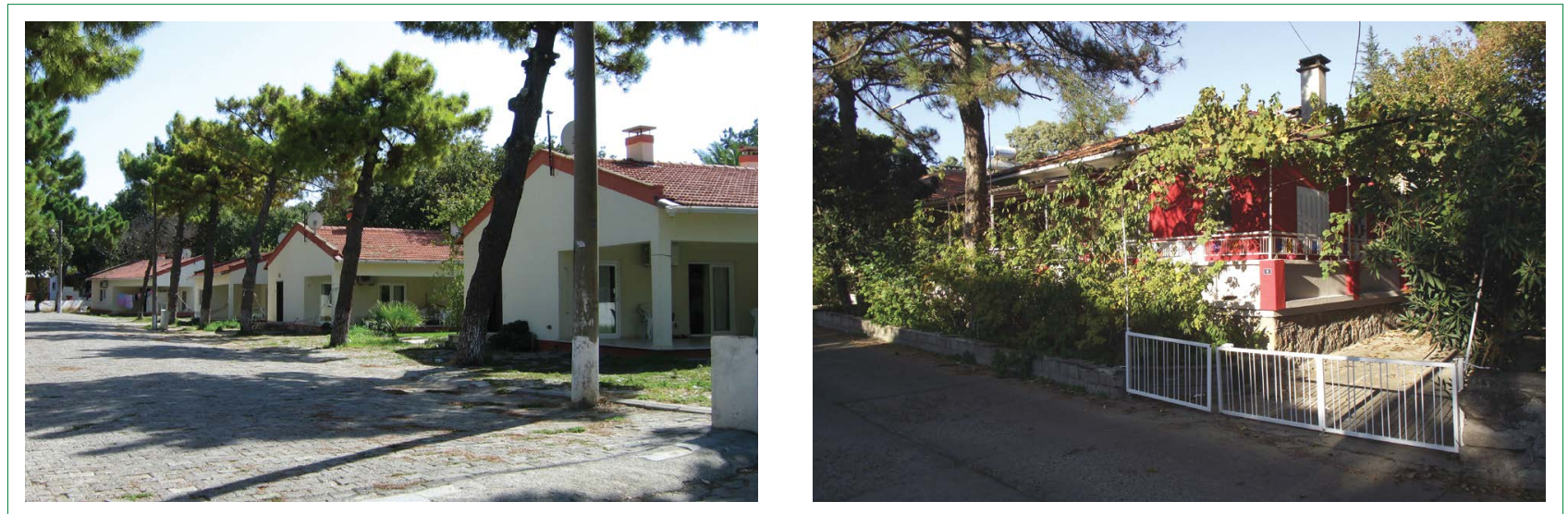

Şekil 6. Ören/Adramytteion Antik Kenti 2. Derece Arkeolojik Sit Alanı'nda bulunan 20. yüzyıl yapıları (2. Yazar, 20I2, 20I3).

taşınır varlıklar, diğer tür anıtlar ve bunların çevresi, ister toprakta ister su altında bulunsunlar, arkeolojik mirasa dahildirler." (TBMM, 1999).

Valetta IIlkeleri;

- "Tarihi kentler, kentsel alanlar ve çevreleri bir bütün olarak ele alınmalıdır. Dengeleri ve özellikleri onları oluşturan parçalara bağlıdır." (ICOMOS, 20II).

Tarihi Kentsel Peyzaja İlişkin Tavsiye Kararı;

- "Tarihi kentsel peyzaj yaklaşımı, fiziki çevrenin korunmasının ötesine geçerek, somut ve somut olmayan tüm nitelikleri de dahil olmak üzere, insanın yaşadığı çevrenin bütününe odaklanmaktadır. Bu yaklaşım mevcut yapılı çevre, somut olmayan kültürel miras, kültürel çeşitlilik, sosyoekonomik ve çevresel etmenlerin yanı sıra yerel toplumsal değerlerini de hesaba katarak, planlamanın ve tasarım müdahalelerinin sürdürülebilirliğini artırmayı amaçlamaktadır." (UNESCO, 20II).

İlk olarak korumanın kapsamı tespit edilmiş, planlama alanında korunması gerekli kültür ve tabiat varlıklarının ayrıntılı bir envanteri oluşturulmuştur. Sit alanı, arkeolojik mirasın korunması önceliğinde yer altı ve yerüstünde çok katmanlı bir kültürel yapı sergilemekte, aynı zamanda Ören halkıyla yaşayan, canlı bir yerleşme içermektedir. Yapılan gözlem ve tespitler sonucunda Ören'de korunması gerekli eserler ve çevrenin sadece arkeolojik mirasla sınırlı olmadığı anlaşılmıştır. Yeraltında, mevcut arkeolojik kazı bulguları ışığında en üstte Bizans döneminden başlayarak, Roma, Yunan, Arkaik dönem, Bronz çağı ve yer yer Kalkolitik döneme uzanan arkeolojik buluntulara oldukça düzenli bir stratigrafi halinde rastlanılmıştır (Özgen, 20।3a) (Şekil 5). Mevcut yerleşme yapısı da 20. yüzyıla ilişkin özgün ve nitelikli bir yapılaşma örneği oluşturmaktadır. Antik kent üzerinde yer alan Ören yerleşim alanı ve yapı varlığının bir kısmı 1950'ler ve 1960'lı yıllarda inşa edilmiş afet konutları (Seylap Evleri), kooperatif evleri ya da münferit çeşitli yapılar gibi dönemlerinin yapı ve tasarım özelliklerini yansıtan diğer bir ifadeyle dönemlerinin nitelikli ve "karakterli” yapılarıdır (Şekil 6).

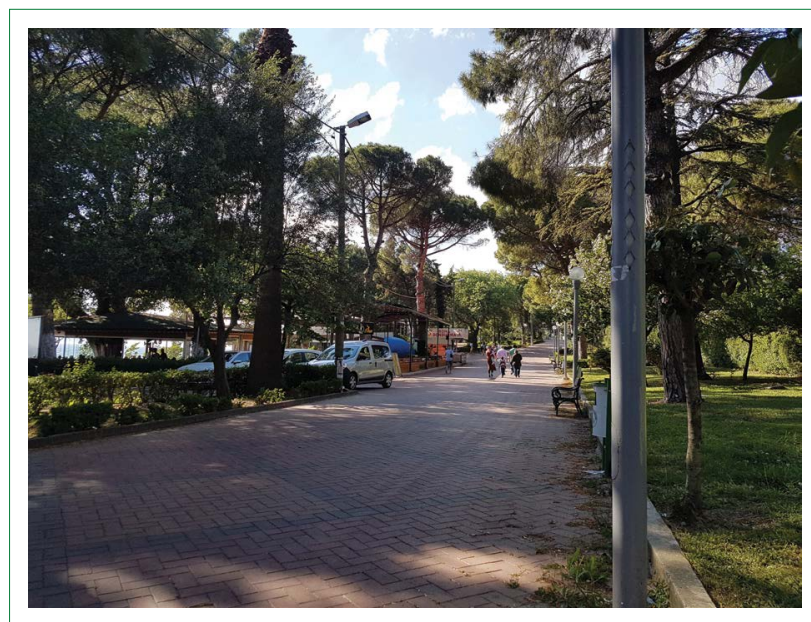

Şekil 7. Ören/Adramytteion Antik Kenti Arkeolojik Sit Alanı, meşe ağaçları ve yeşil doku bütünlüğü (2. Yazar, 20I7).

Arkeolojik mirasın korunması, değerlendirilmesi ve arkeolojik bilimsel araştırma faaliyetlerinin sürdürülmesi öncelikli temel koruma değeridir. Aynı zamanda mevcut yerleşme düzenlerinin de kültürel mirasın bir parçası olarak korunması gerekmektedir. Her ne kadar yapılaşma sürecinde Adramytteion antik kentine ait arkeolojik izlere zarar vermiş olsa da Ören'de 1960'larda oluşmuş sayfiye karakterli ve nitelikli yapılı çevre, sahip olduğu döneminin Türkiye'deki mimarlık ve şehircilik anlayışını yansıtan ve günümüzde örnekleri azalmış olan yapı ve yerleşme dokusu ile korunması gerekli bir kültürel miras olarak değerlendirilmeyi haketmektedir. Bunlara ek olarak, mevcut yerleşme ve yakın çevresindeki yeşil örtü de koruma kapsamında değerlendirilmiştir. Yöreye özgü ve 1003 adedi tescilli toplam 1443 Palamut Meşesi yanı sıra, başta Servi, Çam, Zakkum ve Akasya olmak üzere çeşitli ağaçlardan oluşan yoğun bitki örtüsü ve bakımlı bahçeler de korunması gerekli varlıklar olarak kabul edilmişlerdir (Şekil 7).

Ören yerleşmesinin uzun kumsalı ve kıyı şeridi de korunması gerekli miras ögeleri arasında yer almaktadır (Şekil 8). 


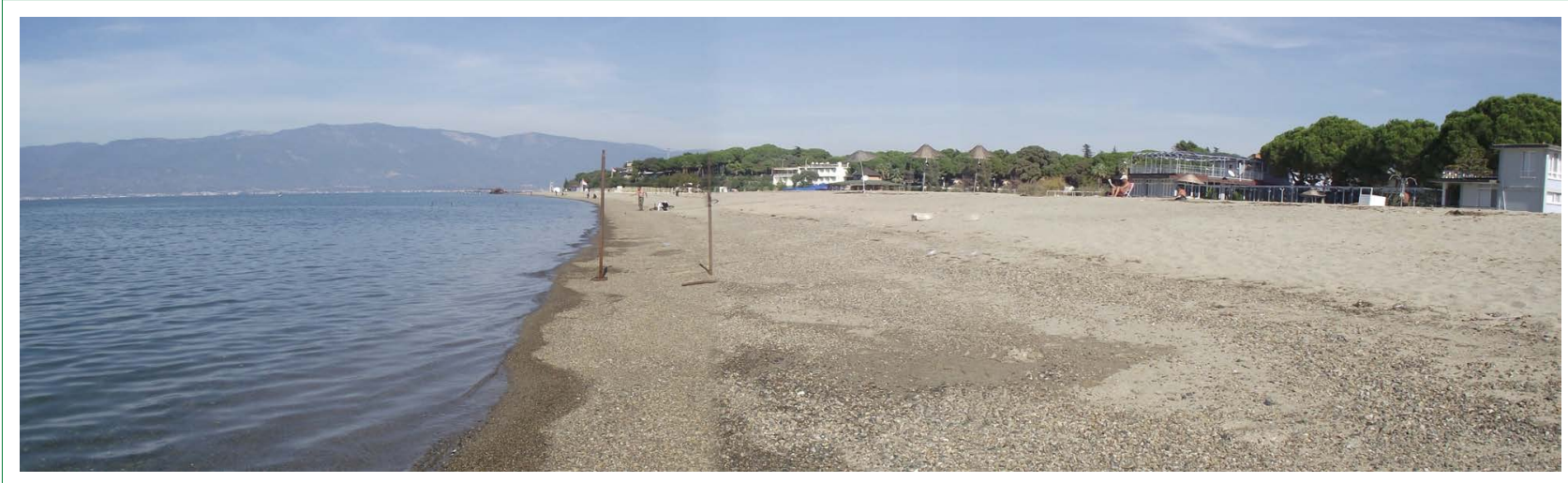

Şekil 8. Ören Kumsalı, güney yönünden bakış (2. Yazar, 20।3).

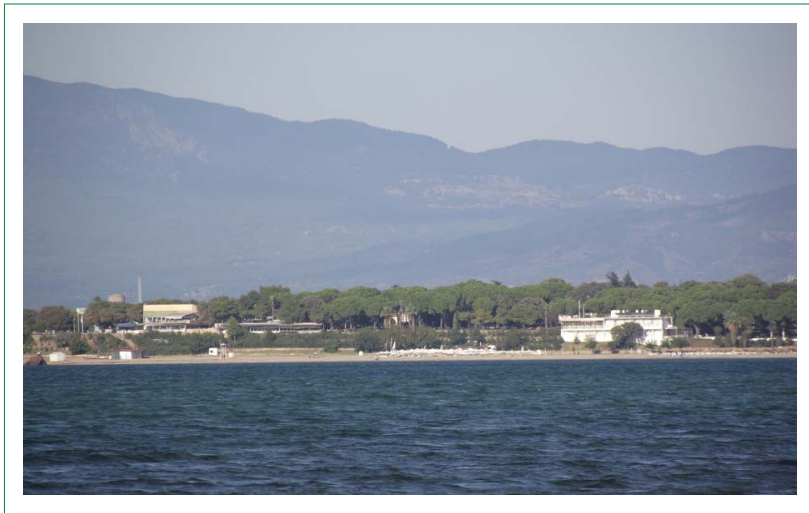

Şekil 9. Ören/Adramytteion Antik Kenti Arkeolojik Sit Alanı'nın denizden görünümü (2. Yazar, 20।3).

Şüphesiz bunlara Ören'in özgün ve yeşil dokuyla bütünleşmiş servilerin vurguladı̆̆ı silueti de eklenmelidir (Şekil 9,

10). Dolayısıyla, Ören'de korunması gerekli miras ögeleri çok katmanlı ve çeşitli bir yapı sergilemektedir. Ören'de plan kapsamında değerlendirilen ve mevcut hali ile korunması gereken miras ögeleri şu şekilde tanımlanmışıิı:

- Adramytteion antik kenti ve diğer dönemlere ait arkeolojik eserler,

- Ören 20. yüzyıl modernist mimarlık mirası: Kooperatif Sayfiye Evleri ve Seylap Evleri ile yerleşme dokuları ve bazı tekil yapılar,

- Ören Tepe ve yakın çevresinin doğal bitki örtüsünün önemli bir parçası olarak Palamut Meşesi ağaçları,

- Ören'de 1960'lardan sonra yapılaşma süreci içinde oluşturulmuş ağaçlandırma ve yeşil doku

- Ören'in yoğun yeşil dokuyla bütünleşmiş ve gerek denizden gerek kara yönünden son derece belirgin silueti

- Ören sahili ve kumsalı

(Günal, Balcı, 2. Yazar, I. Yazar, Özgen, Kutlutan, Karakulak, 2014).

Yukarıda belirtilen ve planlama ekibi tarafından Ören'de koruma kapsamına dahil edilen miras ögelerinin birçoğu yasalarla

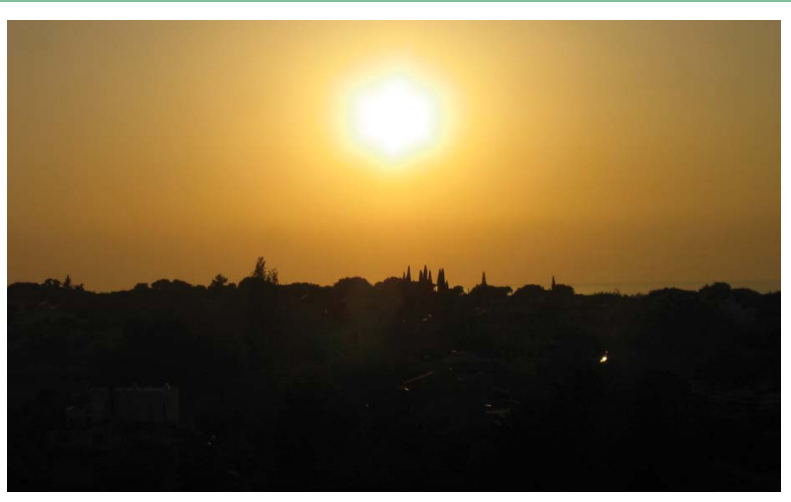

Şekil 10. Ören/Adramytteion Antik Kenti Arkeolojik Sit Alanı'nı silüeti (2. Yazar, 20I2).

korunmamaktadır. Yapılan ayrıntılı analiz, gözlem, tespit ve sahada bilimsel kazı ekibiyle yürütülen ortak çalışmalar sonucunda bölgenin arkeolojik eserler dışında da gerek tekil varlık ve yapı gerekse doku ölçeğinde çeşitlilik gösteren korunması gerekli değerlerinin koruma planı yoluyla kendi kategorilerinde korunmasının sağlanması düşünülmüştür. Plan kapsamında antik kentin korunması sağlanırken tespit edilen söz konusu değerlerin de korunması ve aynı zamanda Ören halkının yaşam alanı olan bu bölgede mevcut yaşamın da sürekliliğinin sağlanması için gerekli düzenlemeler planın amaç ve hedeflerine dahil edilmiştir.

\section{Arkeolojik Sit Alanı Koruma Planı Amaç ve İlkeleri}

Ören halkının yaşadığı bu yerin aynı zamanda kazıların devam ettiği bir arkeolojik sit alanı olması özgün yanlarından birisidir. Planın amacı da Ören'in bu özelliği çerçevesinde biçimlenmiştir. Plan arkeolojik kazıların devamı ve sonrasında kazı ve araştırma alanları ile mimari buluntuların miras değeri olarak koruma altına alınması temelinde çevre standartlarının yükseltilerek yerleşmedeki mevcut yaşamın devamının sağlanmasını amaçlamıştır. Diğer bir deyişle plan en genel anlamıyla gerek arkeolojik araştırma ve kültür mirasının, gerekse yerleşmede- 
ki mevcut yaşamın sürekliliğini yani sürdürülebilirliğini amaç edinmiştir. Bu ilkeler çerçevesinde planın genel vizyonu, "arkeolojik araştırma ve mevcut fiziksel çevre ile buradaki dingin yaşamın sürdürülmesi” amaç ve ilkesine dayalı olarak "kültür mirasıyla bütünleşmiş örnek bir çevrenin oluşmasına ve biçimlenmesine katkıda bulunmaktır" (Günal, Balcı, 2. Yazar, I. Yazar, Özgen, Kutlutan, Karakulak, 20I4). Günümüzde kültürel ve doğal mirasın korunması sadece bir imge, turizm, pazarlama, ekonomik yarar meselesi değildir ve yalnızca bunlarla ilişkilendirilemez. Bahsi geçen bu nedenlerin önemini göz ardı etmemekle birlikte kültürel ve doğal mirasın korunmasında, bu mirasa ait ve bu mirasın temsil ettiği özgün bilginin korunması da son derece değerlidir. Bu açıdan planlama alanında yer alan kültürel ve doğal miras ögelerinin yeniden değerlendirilmesi, plan anlayışına göre ancak yetkin ve doğru koruma yaklaşımları ile anlamlı olacaktır. Sadece belirli bir imge yaratılması ve bunun pazarlanmasını öne çıkaran bir yaklaşımın eksik olacağı açıktır. Plan, bu açıdan öncelikle kültürel ve doğal miras niteliğindeki varlıkların doğru şekilde yani özgün durumlarının olabildiğince korunması ve mevcut fiziksel çevrenin iyileştirilerek, sürdürülmesi ilkesini benimsemiştir.

Geçmişin iz ve birikimlerinin katmanlar halinde tarihsel bir yerleşme sürekliliği oluşturması Ören'e özgü bir durum olmayıp, özellikle Anadolu gibi on binlerce yıldır aralıksız insan varlığı, faaliyetleri ve yerleşmelerine sahne olmuş bir coğrafyada genel bir olgudur. Bu çerçevede, Ören için hazırlanacak bir Koruma Amaçlı İmar Planı kültürel mirasın korunması açısından genel olduğu kadar Ören ve Adramytteion yerleşmelerinin bugünkü durumlarına özgün ilke duyarlılıkları da mutlaka göz önünde bulundurmalıdır. Plan kapsamında Ören için şu koruma ilkeleri esas alınmıştır:

I. Tarihsel ve yerel bilginin geliştirilmesi, paylaşılması, sürdürülebilirliğinin sağlanması

2. Tarihsel kültür mirasının korunması, değer kazandırılması

3. Kültürel mirasın yaşam ve mekânsal deneyimi zenginleştirmesi

4. Kültürel mirasın bütünlük ve zamansal süreklilik içinde ele alınması

5. Yerele özgü çözümler geliştirilmesi

I. Tarihsel ve Yerel Bilginin Geliştirilmesi, Paylaşılması, Sürdürülebilirliğinin Sağlanması

Adramytteion antik kentinin başlıca yapı ve izlerinin ortaya çıkarılması ve bunların uygun şekilde ve yerinde sergilenmesinin sağlanması bu çerçevede son derece önemli ve önceliklidir. Arkeolojik kazılar ve antik Adramytteion kentinin izlerinin ortaya çıkarılarak, buraya ait yeni bilgilerin ortaya konulması, tarih bilinci ve genel olduğu kadar yerele özgü bilginin çoğaltılması ve korunması açısından vazgeçilmezdir. Kültür varlıkları ve bunların içerdiği bilgi, mutlaka topluma kazandırılmalıdır; aksi takdirde anlamsızlaşır (Özdoğan, 2006). Bilginin herkese açık, kullanılabilir bir bilgiye dönüşmesi gerekir. Kültür varlıklarından üretilen bilgi, konunun uzmanı olmayan sıradan kişilerden, yerel, ulusal ve evrensel kimliğe kadar her düzeye, onların anlayacağı, ilgisini çekecek biçimde "erişilebilir bilgiye" dönüştürülmelidir (Özdoğan, 2006).

Kültürel miras sadece fiziksel varlığıyla değil, taşıdığı ve sahip olduğu bilgiyle de önemlidir. Özgünlüğünü yitiren ya da yok olan bir kültürel mirasın kendisiyle birlikte kimi değerli bilgilerin de yok olması anlamına geldiği unutulmamalıdır.

\section{Tarihsel Kültür Mirasının Korunması, Değer Kazandırılması}

Tarihsel kültürel mirasın korunması, bakımı ve kamuoyuyla paylaşılması kadar bu koruma ve paylaşımın nasıl yapıldığı da önem taşımaktadır. Tarihsel kültürel mirasın yerinde korunarak sergilenmesi önemi büyüktür. Seçilecek düzenleme ve tasarımların yerinde koruma ve sergilemeyi destekleyecek yönde olmalı, sitin arkeolojik ve bilimsel niteliğine zarar vermemelidir. Kültürel mirasın sergilendiği fiziksel ortam, korunan mirasın da değerini arttırabilir.

\section{Kültürel Mirasın Yaşam ve Mekânsal Deneyimi Zenginleştirmesi}

Yerleşmelerin işlevsel olduğu kadar yaşayanların gündelik yaşam ve mekâna ilişkin duygu ve deneyimlerini zenginleştirici şekilde düzenlenmesi, planlanması ve tasarımında kültürel mirasın ölçülemez bir değeri vardır. Dünyada Anadolu ölçüsünde zengin ve çeşitli bir kültürel miras zenginliği nadirdir. Bu özgün kültürel miras, ortaya çıkarılma, geri kazanılma, koruma ve değerlendirilme aşamasında kentsel planlama ve tasarımın aktif bir unsuru olarak bireylerin yaşam ve mekân deneyimlerini zenginleştirecek şekilde ele alınmış ve değerlendirilmiştir.

Müze anlayışı içinde çevresindeki yaşamdan arındırılmış ve bir anlamda sterilize edilmiş bir arkeolojik sit ve ören yeri düzenlemesi yerine mevcut yerleşme ve yaşamla birlikte varlığını sürdüren ve bir parçası olduğu yerleşmenin günümüzdeki yaşamına katılan, mevcut yerleşme ve yaşamın doğal, ayrılmaz ve zenginleştirici bir parçası olan bir kültür mirası ve koruma anlayışı benimsenmiştir. Böylesine bir yaklaşım kültürel mirasın kamuoyunca benimsenmesine de değerli katkılarda bulunacaktır

\section{Kültürel Mirasın Bütünlük ve Zamansal Süreklilik İçinde Ele Alınması}

1964 Venedik Tüzüğü'nde de belirtildiği gibi, Ören yerleşmesi Adramytteion antik kentine ait iz ve eserler olduğu kadar, $X X$. yüzyılda bunun üzerinde inşa edilmiş nitelikli yerleşme yapısı ve yapı stoku ile bir bütün olarak görülmüş, bu yönde değerlendirilmiştir. Sadece belirli bir döneme ya da kültüre ait izleri 
Tablo 2. Planlama süreci başlangııında Ören'de mevcut arazi kullanımı

\begin{tabular}{lcc}
\hline İ̧lev & Arkeolojik sit alanı (hektar) & Oran \% \\
\hline Konut, ticaret, hizmet, konaklama alanları & 13.84 & 29.94 \\
Donatı alanları (eğitim, cami) & 0.85 & 1.85 \\
Yol, otopark ve altyapı tesisleri & 8.37 & 18.11 \\
Yeşil alan ve boş araziler & 21.2 & 45.87 \\
Arkeolojik çalışma alanı (kazı) ve taş bahçesi (sergi) & 0.72 & 1.54 \\
Kamp alanı, çocuk oyun alanı, spor alanı, açık hava tiyatrosu & 1.24 & 2.69 \\
\hline
\end{tabular}

Kaynak: I. Yazar, 2013: II8

arayıp, ortaya çıkarmaya çalışmak ve bunu yaparken önceki ya da sonraki dönem ve kültürlere ait eser ve izlere zarar verici bir kültürel miras anlayışı günümüzde geçerliğini yitirdiği gibi, bilimsel yöntem ve etik açısından da doğru değildir.

\section{Yerele Özgü Çözümler}

Ören'in özgün yapısını dikkate alan, bu yapıya duyarlı özgün çözümler geliştirmek de temel koruma ilkeleri arasında yer almaktadır. Ören, belirtildiği gibi yerleşme alanını antik bir şehirle paylaşan yaşayan bir yerleşmedir. Dolayısıyla hem mevcut yerleşme ve buradaki yaşamı ortadan kaldırmayacak, hem de arkeolojik kültürel mirasın ortaya çıkarılması, korunması ve değerlendirilmesini sağlayacak mekâna ve duruma özel çözümler üretilmesi gereği vardır ve koruma imar planında bu yönde bir yaklaşım benimsenmiştir (Günal, Balcı, 2. Yazar, I. Yazar, Özgen, Kutlutan, Karakulak, 20।4:8, 9).

\section{Arkeolojik Sit Alanı Koruma Planı Stratejileri ve Kararları}

I. ve 2. derece arkeolojik sit alanı içinde yeni yapı yapılması mümkün değildir (KTVKYK 658 sayılı ilke kararı). Var olan yapılar kullanılmaya elverişli olduğu süre varlıklarını devam ettirecekler, yıkıldıkları veya yaşanamaz derecede yıprandıklarında yerine yenisi yapılamayacaktır. I. derece arkeolojik sit alanı 7,19 hektardır ve üzerinde herhangi bir yapı yoktur tamamı boş arazilerden oluşur. 2 . derece arkeolojik sit alanı 39,02 hektardır ve bu alan üzerinde 310 yapı bulunmaktadır. Bu yapılar 2. derece arkeolojik sit alanının \%52,6'sını kaplar ve konut, konaklama, ticaret ve donatı başta olmak üzere farkIı kullanımlara sahiptirler. Alanın diğer \%46'si ise yeşil (park, ağaçılık alan vb.) ve boş alanlar yer alır (Tablo 2 ).

Arkeolojik bilimsel araştırmaların kentsel doku ile birlikte nasıl bir düzen içerisinde devam edeceği üzerine kazı ekibi ile birlikte temel bazı kararlara ulaşııışıı. Bu noktada 1956 yllında Yeni Delhi'de yapılan UNESCO Genel Konferansında "Arkeolojik Kazılarda Uygulanacak Uluslararası Illkeler Tavsiye Kararı" nı incelemekte fayda vardır. Tavsiye kararı 33 mad- deden oluşmaktadır. 9. Madde'ye göre insanlık tarihi ile ilgili bilgiler sağlayan arkeolojik mirasın korunmasında her döneme ait arkeolojik sitlerden örnekler seçilerek, bu alanların bir kısmının veya tümünün gelecek için rezerv arkeolojik kaynaklar olarak dokunulmadan saklanması ve gelecekte daha ileri arkeolojik bilgi birikimi, yöntemi ve teknoloji ile araştırma yapılması imkânı sağlanması istenmektedir. Arkeolojik araştırmaların amacının sadece toprak altındaki eserlerin ortaya çıkarılması olmadığı, insanlık tarihini şekillendirecek bilginin elde edilmesinin ası amaç olduğu vurgulanmaktadır. En önemlisi de bu madde ile "rezerv arkeolojik alanlar" kavramı ortaya çıkmaktadır. 1990 ICOMOS Arkeolojik Mirasın Korunması ve Yönetimi Tüzüğü'nde, Arkeolojik rezerv alanlarının yaratılması kültürel mirasın koruma politikalarının bir parçası olması gerektiği vurgulanmaktadır. Bu konuda politikalar üretmek için rezerv arkeolojik alanlar koruma imar planları kapsamında düşünülerek, rezerv alanlar planlarda gösterilmelidir. Bu durumda arkeolojik bilimsel çalışma alanları da kendi içinde sınıflandırılarak koruma planlarıyla bu alanlar için özellikli kararlar üretilmesi sağlanabilir. Nitekim Adramytteion arkeolojik sit alanında 58 sondaj yapılmış ve kazı ve sondaj alanında elde edilen bulgular haritalara işlenerek yapılan kapsamlı envanter çalışması ile birlikte coğrafi bilgi sistemleri ortamında arkeolojik sitin topografyası elde edilmeye çalışımıştır. Arkeolojik bilimsel araştırma ekibi araştırma ve plancılar ile yürütülen bu çalışmalar koruma planına aktarılmış I. ve 2. derece arkeolojik sit alanında yer alan arkeolojik bilimsel araştırmaların yürütüldüğü kazı alanları, yakın gelecekte araştırma faaliyetlerinin devam edeceği alanlar ve bunların dışındaki kalan rezerv arkeolojik alanlar olarak belirlenmiştir. Böylesi bir sınıflandırmanın mevzuata göre koruma planlarında gösterilmesi mümkün değildir, fakat aslında korunan sitteki arkeolojik bilimsel çalışmaların geleceğinin planlaması olarak değerlendirilmelidir. Bu çalışmanın sonuçları mevzuatın el verdiği ölçüde Adramytteion Arkeolojik Sit Alanı Koruma Amaçıı İmar Planına aktarılmıştır.

Arkeolojik kazı çalısmaları ile ortaya çıkan buluntuların, kazı alanlarının düzenlenerek korunması, topluma kazandırıması ve yaşayan kent ile bütünleştirilmesi Adramytteion arkeolojik 


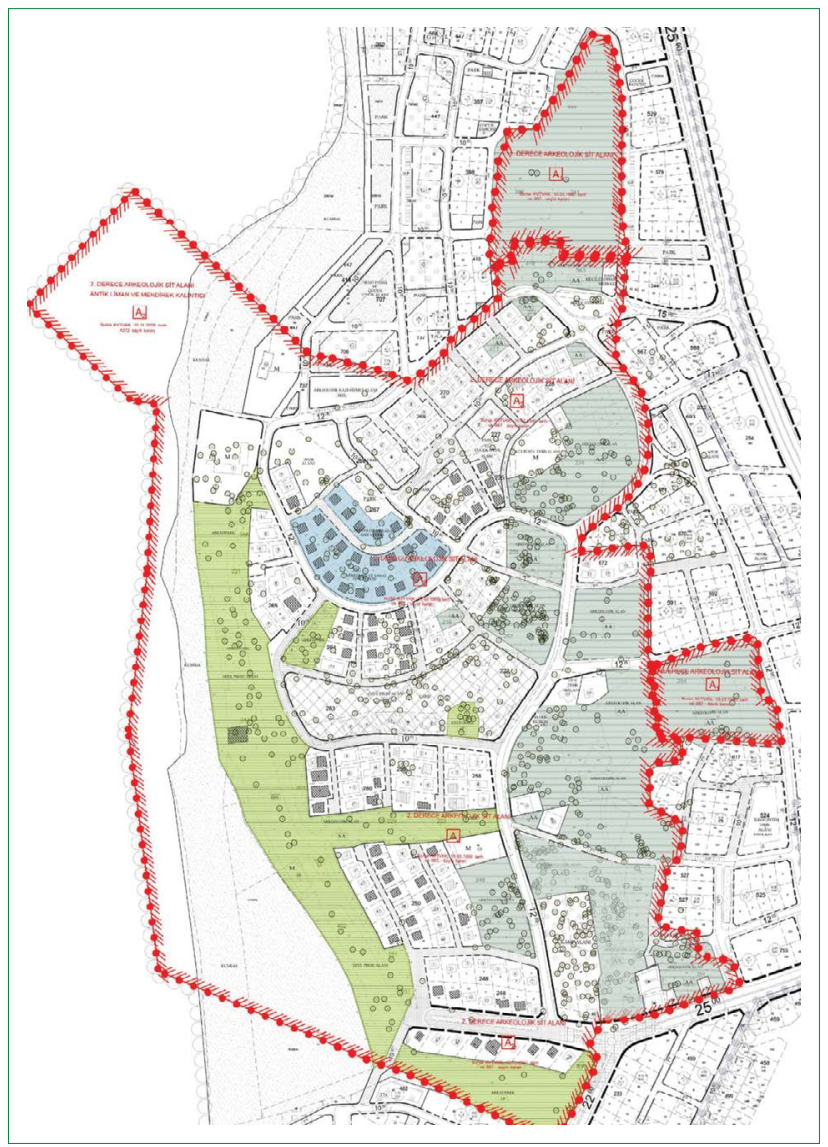

Şekil I I. Adramytteion Antik Kenti Arkeolojik Sit Alanı Koruma Amaçlı İmar Planı'ndan bir örnek, 20I4. Bu plan örneğinde arkeolojik rezerv alanları (koyu yeşil boyalı alanlar), arkeopark alanı (açık yeşil boyalı alanlar), arkeoloji ve sanat atölyeleri (mavi boyalı alan), tescil önerisinde bulunan 20. yüzyıl yapıları (içi çapraz taralı yapılar) ve tescil önerisinde bulunan ağaçlar (yuvarlak semboller) yer almaktadır. Parsel numarasıyla gösterilen yapılar ise mevcut yapılar ile yıkıldı̆ında yerine bir daha yapı yapılamayacak parselleri göstermektedir.

sit alanı koruma amaçlı imar planı hedeflerindendir. Bu hedef doğrultusunda antik kentin ve arkeolojik kazıların yöreye kazandırdığı tarihsel ve arkeolojik kimliğe uygun ve uyumlu olarak Ören'e arkeoloji temelli ve temalı bir kamusal yeşil alan kazandırma fikri yani arkeolojik park önerisi uygun görülmüştür. Arkeopark, tarihsel değerler ve kent kullanıcılarının rekreasyonel faaliyetlerini karşılama unsurlarını taşıyan kültürel ve arkeolojik miras yönetimi ile kentsel rekreasyonel faaliyetlerin birlikte sunulduğu kent içinde yeni bir yorumlama merkezidir (Tuna ve Erdoğan, 2016). Ören /Adramytteion Arkeolojik Parkı, kazı alanlarını ve Ören kıyı aksını içerir (Şekil II). Halihazırda Ören'de kıyı aksı boyunca uzanan yaya alanı hemen hemen tümüyle gezinti ve yeme-içme ihtiyaçlarına hitap etmektedir. Bu yanlış olmasa da arkeolojik açıdan böylesine kıymetli bir alan ve değerli konum için önemli eksiklikler içeren bir kullanımdır. Bu sebeple kıyı aksının koruma planında arkeopark alanı olarak kentsel tasarım projeleriyle düzenlenmesi öngörülmüştür.

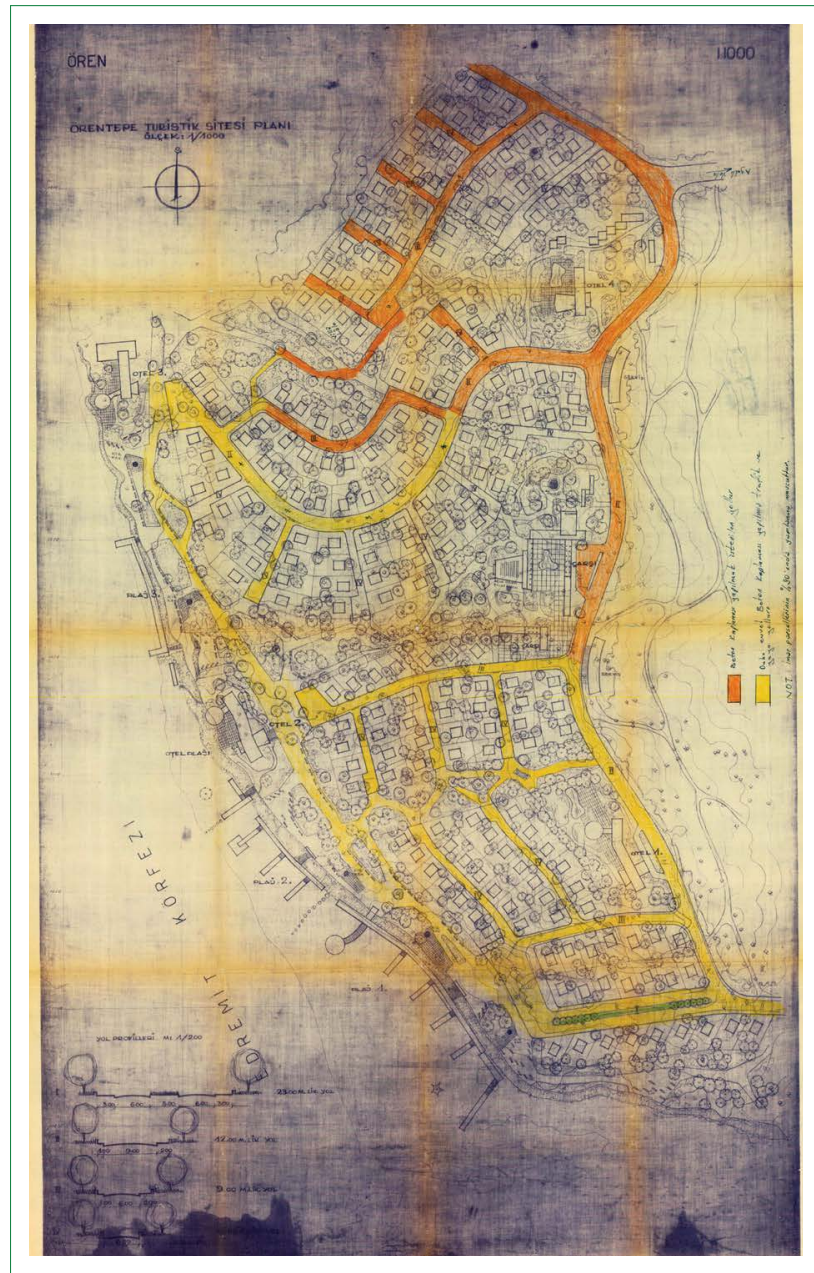

Şekil I 2. 1957 yılında Abdullah Ardalı ve Nihat Güner tarafından yapılan Ören Vaziyet Planı (Kaynak: Burhaniye Belediyesi).

Arkeolojik mirasın korunmasıyla ilgili politikalar arazi kullanımı, gelişme ve planlama kadar kültürel, çevresel ve eğitim politikalarının önemli bir bileşeni olmalıdır (ICOMOS, 1990). Arkeolojik mirasın korunmasında halkın katılımı sağlanmalı, halka arkeolojik bilimsel çalışmalar ve tarihsel bilginin söyleşi, seminer ve halk toplantıları ile aktarılması katılımın başlangıç aşaması olarak değerlendirilmelidir. Koruma planları da bu yönde geliştirilen politikaların bir parçasıdır ve bu faaliyetlerin yürütüleceği mekanların kentsel hizmet alanları olarak belirlenmesine imkân verir. Nitekim Ören'de halihazırda var olan yapı stoku bu tür faaliyetleri karşılayacak niteliktedir. Geniş bahçeli tek katlı yapılardan oluşan kamu mülkiyetindeki Seylap Evleri'nin bir kısmı bu amaçla "Arkeoloji Atölyeleri”, buna komşu alan da "Sanat Atölyeleri" olarak planda ayrılmıştır (Şekil II). Arkeolojik bilimsel araştırmalar için gerekli olan kazı evi, depolar ve konaklama gibi ihtiyaçların karşılanması amacıyla arkeolojik hizmet alanı yine sit alanı içinde planlanmıştır.

Ören mevcut yerleşme düzeni ve ilk yapı stoku, 1957 yılında Mimar-Şehir Plancısı Abdullah Ardalı ve Mimar Nihat Güner 
tarafından hazırlanan I//000 ölçekli Ören Vaziyet Planı uygulamasıyla gerçekleşmiştir. Söz konusu yerleşme alansal büyüklük ve konut sayısı açısından küçük boyutlu sayılabilecek bir uygulama olmasına karşın Ankara Bahçelievler, Yenimahalle, İstanbul Levent, Koşuyolu v.b. "bahçeşehir" anlayışının Türkiye'deki iyi ve nitelikli örneklerinden biri olmuştur (Şekil I2).

$\mathrm{Bu}$ nitelikli kentsel dokunun ve yapıların koruma altına alınabilmesi için yasalarla da korunuyor olması doğal afet veya bireysel tercihlerle yıkılıp terk edilmesine karşı önlem alınması gerekmektedir. Fakat ülkemizde 20. yüzyıl modern yapı ve dokuları için tescil ve sit alanı olarak koruma altına alınması alısık olunmayan bir durumdur. Mevcut mevzuat bu yapıların da korunmasına imkân vermesine rağmen koruma kurulları bu konuya her zaman anlayışla bakmamaktadır. "Insanlar bir modern binanın kültürel değerini kavramakta zorlanmakta; bazı kurul üyeleri yakın tarihli projelerin değeri konusunda yeterli birikime sahip bulunmamaktadır" (Ahunbay, 2018). 20. yüzyıl mimarlığı için değer tanımları ve koruma ölçütleri henüz gelişmemiştir. (Madran, 2006). 20. yüzyıl mimarlığının, planlı yerleşmelerinin tescili için, tarihî öneme sahip olmaları, estetik değer taşımaları, içinde bulundukları tarihî yerleşmenin gelişimine katkıları olması, belli bir dönemin kent yaşamı, planlaması hakkında veri sağlamaları, özel bir tasarıma, taşıyıcı sisteme, tipolojiye sahip olmaları, ünlü bir mimarla ilişkili olmaları gibi ölçütler aranmaktadır. Bu özelliklere sahip olan yapılar veya yerleşmeler tescil edilerek yasal koruma altına alınmaktadır (Ahunbay, 2018). Adramytteion Sit Alanı Koruma Planı Analitik Etüd çalışmaları sırasında söz konusu bu değerler açısından Kooperatif ve Seylap Evleri MSGSU Mimarlık Fakültesi Restorasyon Bilim Dalı öğretim üyeleri tarafından sahada incelenmiştir. Bu konuda sundukları raporda; "Arkeolojik sit alanı üzerinde yer alan ve 20. yüzyılın modern planlama ve tasarım anlayışında inşa edilmiş, 52 Evler olarak bilinen kooperatif alanı ile Seylap/Afet Evleri yeni bir sosyal strateji barındırması ve 20. yüzyılda değişen yaşam biçimini yansıtması sebebiyle sosyal değere sahip olduğu tespit edilmiştir" (Kaptı, Kıraç, Çoşkun, 20145). “1955 yılında Gömeç-Yayaköy’deki sel felaketi sonrası evleri yıkılan 5I aileye, devletçe Ören Tepe'de inşa edilen 55 adet afet evinden oluşan Seylap/Afet Evleri 20. yüzyılın sosyal konut projelerinin ilk örneklerinden olması bakımından hem sosyal hem de referans olma değerine sahiptir" (Kaptı, Kıraç, Çoşkun, 20I4). Bu sebeple, Kooperatif ve Afet Evleri (Seylap Evleri) yerleşimlerinin deprem bölgesinde oldukları göz önünde tutularak ve yerleşimler sahip oldukları değerler de dikkate alınarak "modern mimarlık mirası" olarak tescil edilmeleri uygun olacağı belirtilmektedir" (Kaptı, Kıraç, Çoşkun, 2014).

2012 yılından beri her yıl yapılan gözlem incelemeler sonucu Belediye mülkiyetinde olan Seylap Evleri başta olmak üzere çarşı, park ve rekreasyon alanlarında yıpranma ve bozulmaların zamanla artığı, Seylap Evleri'nin ucuz konaklama imkanı veren pansiyonlar olarak belediye tarafından kiraya verilmesinin bu yapılarda fiziksel yıpranmayı hızlandırdığı ve herhangi bir bakım çalışması yapılmadığı görülmüştür. Ören yaz aylarında kumsal, deniz, meşe palamutlarının oluşturduğu yeşil doku ve sahilde geniş park alanları sebebiyle yoğun talep görmekte, talebi karşılamak üzere niteliksiz çay bahçeleri ve yeme-içme, eğlence mekanları her geçen yıl genişleyerek çevresine doğru yayılmaktadır. Belediye ve Ören halkı ise mekân kalitesinin büyük yatırımcılarla düzeleceğini düşünerek komşu ilçesi Ayvalık’a özenmektedir.

Koruma planı bu sorunların üstesinden gelmek mekân kalitesinin koruma anlayışı çerçevesinde iyileştirilmesini sağlayabilmek için söz konusu kentsel dokunun ve binaların koruma altına alınması ve kültür mirasına dahil edilmesini plan kararı önerisi olarak getirmiştir. Tescilli ve henüz tescillenmemiş olan 440 palamut ağacının da tescil önerisi planda yer almaktadır (Şekil II). Arkeolojik araştırma ve mevcut fiziksel çevre ile buradaki dingin yaşamın sürdürülmesi, kültür mirasıyla bütünleşmiş örnek bir çevrenin oluşması için Ören sayfiye yerleşmesi kimliğinin arkeoloji ve sanat kimliğiyle yer değiştirmesinin doğru olacağı görülmüştür. Koruma planı stratejisi olarak planlama alanında başlıca altı farklı müdahale biçimi öngörmüştür. Bunlar; koruma, işlevsel dönüşüm, iyileştirme, tasfiye, dondurma ve yapılaşmadır.

- Koruma: Koruma kapsamındaki alanlar, kültürel miras niteliğinde olan, mevcut ya da gelecekteki (rezerv) arkeolojik kazı ve araştırmalara ayrılmış "Arkeolojik Alan" statüsündeki alanlar,

Koruma: Ören'deki modern yerleşmenin başlangııını oluşturan 20. yüzyıl kültür mirası niteliğindeki Kooperatif Evleri ile Seylap Evleri ve dönemlerinin çizgilerini yansıtan bazı tekil yapilar.

Bu alanlarda mevcut yerleşme, doğal doku ve yeraltındaki potansiyel arkeolojik varlıklar koruma kapsamında değerlendirilmişlerdir.

- İşlevsel Dönüşüm: Planlama alanında fiziksel çevresi korunurken, içinde barındırdığı işlevlerin dönüşümü önerilen alanları kapsamaktadır. Seylap Evleri'nde mevcut fiziksel çevre ve yerleşme yapısı korunurken, mevcut turizm işlevinin arkeoloji ve eğitim; "Arkeoloji Atölyeleri" ve "Sanat Atölyeleri”nde ise, alanın sanat amaçlı dönüşümü öngörülmüştür.

- lyileştirme: Planlama alanında mevcut konum ve işlevleri korunarak, iki yerde iyileştirme öngörülmüştür. Kıyı boyunca uzanan yaya bölgesinden oluşan "Arkeoloji ParkıArkeopark" alanı ile mevcut ticaret faaliyetleri hediyelik eşya ve yeme içmeye birimlerini içeren "Çarşı" alanıdır. Bu

5 Kaptı, Kıraç ve Çoşkun tarafından yapılan saha çalışmaları sonrasında hazırlanan rapor, "Kültür Mirası Olarak Ören Yerleşme Dokusu” adıyla Burhaniye / Ören Adramytteion Arkeolojik Sit Alanı Koruma Amaçlı İmar Planı Analitik Etüd’ünde yer almaktadır. Bu rapor, yayınlanmamış bir rapordur. 
alanlarda ayrıca hazırlanacak kentsel tasarım projeleriyle mevcut işlevlerin ve yer aldıkları fiziksel çevrelerin iyileştirilmesi ve Arkeoloji Parkı-Arkeopark örneğinde olduğu gibi, ticaret alanında da yeni bir tema ile zenginleştirilmesi önerilmiştir.

- Tasfiye: Sınırlı ölçüde mevcut işlev ve/veya fiziksel çevre/ yapıların tasfiyesinin öngörüldüğü alanları kapsamaktadır. Bunlar, aynı zamanda Kıyı Kanunu'nun, kıyı kenar çizginden itibaren ilk 50 ve ilk 100 m. mesafe içinde kalan, çoğunlukla turizm ya da konut amaçlı yapıların yer aldığı alanlardır. $\mathrm{Bu}$ alanlarda öngörülen tasfiye de ancak mevcut yapıların zaman içinde doğal nedenlerle tahribi ya da yıkılması ile gerçekleşebileceğinden burada tasfiye zamana yayılmış bir uygulamayı oluşturmaktadır.

- Dondurma: 2. Derece Sit Alanı içinde yer alan yapı ve kullanımlar sit kararlarında olduğu gibi plan kapsamında da dondurulmuştur. Bu durumdaki yapı ve parseller için herhangi bir imar/yapılaşma hakkı öngörülmemiş, ancak, mevcut yerlerinde, mevcut fiziksel durumlarıyla kullanımlarının devamı öngörülmüştür.

- Yapılaşma: Etkilenme/Geçiş Bölgesi'nde müze denetimli temel kazısı şartıyla, arkeolojik sit alanı ile uyumlu düşük yoğunluklu alanlar olarak planlanmıştır.

\section{Sonuç}

Adramytteion Arkeolojik Sit Alanı, Ören halkının yaşadığ ve aynı zamanda arkeolojik bilimsel faaliyetlerin devam ettiğ bir alan olması nedeniyle koruma imar planının benimsediğ amaç, ilke ve plan kararları ile ülkemiz için önemli bir örnek oluşturma özelliği taşımaktadır. Planın hem kültür mirasının korunmasına ve değerlendirilmesine, hem de yerleşmedeki mevcut yaşamın sürekliliğini yani sürdürülebilirliğini amaç edinmesi antik kentin günümüz yaşamıyla tekrar buluşmasına ve Ören'in kültür varlıklarıyla değer kazanmasına imkân verecektir. Adramytteion Arkeolojik Sit Alanı Koruma Amaçlı İmar Planı Bursa Kültür Varlıkları Koruma Bölge Kurulu ile başlayan plan onama sürecinde 3 yıl bekledikten sonra onaylanıp, 2015 yılında idari olarak kurulup, 2017 yılında faaliyete geçen Balıkesir Kültür Varlıkları Koruma Bölge Kurulu'na devredilmiştir. Her iki kurulun üyelerinin de koruma planın amaç ve ilkelerini benimsemekte zorluk çektikleri söylenebilir Bursa Kültür Varlıkları Koruma Bölge Kurulu 20. yüzyıl kültür değerlerinin imar planında tescillenerek korunması önerisini anlamlı bulmamış ve planı bu yöndeki koruma kararını kaldırıp onaylayarak, dağıtım amacıyla Balıkesir Kültür Varlıkları Koruma Bölge Kurulu'na sevk etmiştir. Balıkesir Kültür Varlıkları Koruma Bölge Kurulu tarafından tekrar onay süreci başlatılan Adramytteion Arkeolojik Sit Alanı Koruma Amaçlı İmar Planı şu an kurul onay aşamasındadır. Fakat bu değişiklik ile planın bütünsel koruma amacı zarar görmüş, planın koruma ilkelerinden birisi ortadan kaldırılmıştır. Bununla birlikte Bursa Kültür Varııları Koruma Bölge Kurulu planı onaylarken, mevcut yer- leşme dokusunun korunmasını da sağlıyormuş gibi, sit alanları ve etkileşim-geçiş sahası için "Kentsel Tasarım Rehberi” ve "Mimari Tipoloji Envanteri” gibi iyi niyetli ancak, henüz yasal mevzuatımızda yer almayan iki çalışma daha yapılması kararı almıştır. Burhaniye Belediyesi'nin o dönemde bu konudaki isteksizliği nedeniyle gerçekleşmeyen bu çalışmaların uygulamada ancak referans nitelikli olabileceği, koruma açısından tescil kararı gibi bir yasal yaptırıma sahip olamayacağı açıktır.

Sonuç olarak, Adramytteion Arkeolojik Sit Alanında olduğu gibi günümüz yerleşmesiyle çakışan arkeolojik sitlerde modern yaşam ile korunan kültür mirasının birlikteliği bir zenginlik, yerin kimliğini oluşturan bir değer ve yerin sürdürülebilir kalkınmasında bir fırsat olarak görülmelidir. Korunan kültür mirası ile günümüz yaşamının bütünsel olarak değerlendirilerek, mirasın korunması ve gelecek yaşamın gereklerinin dengelendiği, mekânsal kaliteyi artırarak ekonomik ve sosyal yaşamı kültürel zenginliğin odağında geliştiren koruma plan ve politikalarının benimsenmesi gerekmektedir. Söz konusu bu anlayışta değerlendirilen koruma amaçlı plan ve politikaları, yerin bugün yaşayan sahiplerinin yerin tarihsel kimliğini sahiplenmesine, kültürel mirasın içerdiği bilginin gelecek nesillere aktarılmasına ve toplumda koruma bilincinin oluşmasına da imkân verecektir. Farklı dönemlere ait kültür izlerinin anlaşıması ve değerlendirilmesi amacıyla plan çalışmalarında arkeolog, kent plancısı, mimar gibi çok disiplinli bir ekip ile kapsamlı kültür envanteri çalışmasının yürütülmesi ve yerleşimin arkeolojik-mimari ve doğal topografyasının haritalandırılması diğer bir anlatımla tarihi, doğal ve yapıl çevreyi bütünsel olarak ele alan bir çalışma plan kararlarının bu yönde alınmasını sağlayacaktır.

Ayrıca, kültür mirasın korunmasında uluslararası düzeyde 21 . yüzyılda sözleşme, tüzük ve tavsiye kararlarında yeniden şekillenen tanım, kavram ve koruma anlayışının ülkemiz yasal sistemine daha hızlı aktarılarak uyumu sağlanmalıdır. Kültürel mirasın korunmasında güncel bakış açılarını içeren koruma planlarının yapılabilmesi ve bu konuda yaşanan sorunların çözüme kavuşmasında bu uyum oldukça önemlidir. 


\section{KAYNAKLAR}

Yazar (2013). “Fiziki Mekan Araștırmaları”, Burhaniye / Ören Adramytteion Arkeolojik Sit Alanı Koruma Amaçılı İmar Planı. Analitik Etüdler. Cilt II. Planlama Alanına İlişkin Araştırmalar. (Yayınlanmamış rapor). Promer Planlama, s.115-151.

2. Yazar (2013a). Ören: Tarih ve Mekansal Gelişim", Burhaniye / Ören Ad ramytteion Arkeolojik Sit Alanı Koruma Amaçlı İmar Planı. Analitik Etüdler. Cilt II. Planlama Alanına İlişkin Araştırmalar. (Yayınlanmamış rapor). Promer Planlama, s.40-54.

Yazar (2013b). “Korumaya İlişkin Veriler”, Burhaniye / Ören Adramytteion Arkeolojik Sit Alanı Koruma Amaçı İmar Planı. Analitik Etüdler. Cilt II. Planlama Alanına İlişkin Araştırmalar. (Yayınlanmamış rapor). Promer Planlama, s.55-64.

Ahunbay, Z. (2010). Arkeolojik Alanlarda Koruma Sorunları Kuramsal ve Yasal Açılardan Değerlendirme. Türkiye Bilimler Akademisi Kültür Envanteri Dergisi (TÜBA-KED), 8, 103-118. http://tubaked.tuba.gov.tr/ index.php/tubaked [14 Aralık 2018]

Ahunbay, Z. (2017). Tarihi Çevre Koruma ve Restorasyon. İstanbul: Yem Yayinları.

Ahunbay, Z. (2018). 20. Yüzyıl Mimarlığının Korunması ve AKM. Mimarlık, 399, Mimarlar Odası, Ankara. http://www.mimarlikdergisi.com/index. cfm?sayfa $=$ mimarlik \&DergiSayi $=413 \&$ RecID $=4347 \# \quad[20$ Temmuz 2019]

Bandarin, F. (2019) Resahaping Urban Conservation. Roders, A. P., Bandarin, F. (Ed.), Reshaping Urban Conservation, The Historic Urban Landscape Approach in Action. İçinde (s. 3-20). Singapur: Springer.

Bartolomeo, S. (1485). Isolario. Venedik.

Beksaç, E. (2002). 2000 Yılı Balıkesir İli, Ayvalık, Gömeç, Burhaniye ve Edremit İlçelerinde Pre ve Protohistorik Yerleşmeler Yüzey Araştırması. 19. Araştırma Sonuçları Toplantısı, Cilt 2.

Beksaç, E. (2003). 2002 Yılı Balıkesir İli, Ayvalık, Gömeç, Burhaniye ve Edremit İlçelerinde Pre ve Protohistorik Yerleşmeler Yüzey Araştırması. 20. Araştırma Sonuçları Toplantısı.

Beksaç, E. (2004). Balıkesir İli, Ayvalık, Gömeç, Burhaniye, Edremit ve Hav ran İlçelerinde Prehistorik ve Protohistorik Yerleșmeler Yüzey Araştırması 2002. 21. Araştırma Sonuçları Toplantısı Cilt 1.

Bostan, İ. (1992). Osmanlı Bahriye Teşkilâtı: XVII. Yüzyılda Tersâne-i Âmire. Ankara: TTK Basımevi

Çoruhlu, T. (2006). Ören (Adramytteion Antik Kenti) 2005 Yllı Kazı Çalışması, 28. Kazı Sonuçları Toplantısı, 1. Cilt.

Çoruhlu, T. (2007). Ören (Adramytteion Antik Kenti) 2005 Yılı Kazı Çalış ması, 29. Kazı Sonuçları Toplantısı, 3. Cilt.

Council of Europe, Cultural Heritage Committee, (2000). A European Code of Good Practice: "Archaeology and the urban project". http://www.izen pe.eus/s154812/es/contenidos/informacion/manifiestos_patrimonio/ es_8658/adjuntos/DOC67.pdf [23Temmuz 2019]

Council of Europe, Cultural Heritage Committee, (2005). Convention on the Value of Cultural Heritage for Society, Faro Convention, https://www. coe.int/en/web/culture-and-heritage/faro-convention, [20 Eylül 2019]

Çapar, Ö. (1995). “Románın Asia Eyaletinde Conventus (Diocesis) Sistemi”, DTCF Dergisi. Nol. 37. s. 731-755.

Department for Communities and Local Government. (1990). Planning Policy Guidance 16: Archaeology and planning. http://www.communities. gov.uk, [20 Eylül 2019]

Dinçer, İ. (2013). Kentleri Dönüştürürken Korumayı ve Yenilemeyi Birlikte Düşünmek: “Tarihi Kentsel Peyzaj” Kavramının Sunduğu Olanaklar. In ternational Journal of Architecture and Planning Volume 1, (1), s.22-40.

Distelrath, A. (2011). Miras 1, Yerleșim ve Yaşam Alanı Olarak Ören Yeri, Herakleia (Latmos) için bir Koruma Konsepti. İstanbul: Ege Yayınları.

Güçer, E. (2004). Archaeology and Urban Planning A Consensus between Conservation and Development: Geyre and Aphrodisias. (Yayınlanma- mış yüksek lisans tezi). İzmir: İzmir Teknoloji Enstitüsü

Günal, İ., Balcı, S., 2. Yazar, 1. Yazar, Özgen, H. M., Kutlutan, R., Karakulak, Y. S. (2014). Burhaniye Ören/Adramytteion Arkeolojik Sit Alanı 1/5000 Ölçekli Koruma Amaçlı Nazım İmar Planı Açıklama Raporu ve Plan Notları. (Yayınlanmamış rapor). Promer Planlama.

ICOMOS,(1990).ArkeolojikMirasın Korunmasıve Yönetimi Tüzüğü.http:// www.icomos.org.tr/Dosyalar/ICOMOSTR_0844861001353670083. pdf, [2 Kasim 2018].

ICOMOS, (2011). Tarihi Kentlerin ve Kentsel Alanların Korunması ve Yönetimiyle İlgili Valetta İlkeleri, http://www.icomos.org.tr/Dosyalar/ICOMOSTR_tr0592931001536912260.pdf, [20 Temmuz 2019]

Kaptı, M., Kıraç, B., Çoşkun, S. (2013).“Kültür Mirası Olarak Ören Yerleşme Dokusu”, Burhaniye / Ören Adramytteion Arkeolojik Sit Alanı Koruma Amaçlı İmar Planı. Analitik Etüdler. Cilt II. Planlama Alanına İlişkin Araştırmalar. (Yayınlanmamış rapor). Promer Planlama, s.163-177.

Kretschmer, K. (1909). Die italienischen Portolane des Mittelalters: ein Beitrag zur Geschichte der Kartographie und Nautik. Berlin: E. S. Mittler und Sohn.

Kültür ve Turizm Bakanliği, (1983). 2863 Sayll Kültür ve Tabiat Varlıklarını Koruma Kanunu. https://www.mevzuat.gov.tr/MevzuatMetin/1.5.2863.pdf [5 Kasım 2018].

Kültür ve Turizm Bakanliği, Kültür ve Tabiat Varlıklarını Koruma Yüksek Kurulu, (1999). 658 nolu İlke Karar1, Arkeolojik Sitler, Koruma ve Kullanma Koşulları. https://kvmgm.ktb.gov.tr/TR-44305/kultur-ve-tabiatvarliklarini-koruma-yuksek-kurulu-ilke-html, [5 Kasım 2018].

Kültür ve Turizm Bakanliği, Kültür ve Tabiat Varlıklarını Koruma Yüksek Kurulu, (2005). 702 nolu İlke Kararı, Kentsel Arkeolojik Sit Alanları Koruma ve Kullanma Koşulları. https://kvmgm.ktb.gov.tr/TR-44305/ kultur-ve-tabiat-varliklarini-koruma-yuksek-kurulu-ilke-.html, [5 Kasim 2018].

Kültür ve Turizm Bakanlığı, (2018). Kültür Varlıkları ve Müzeler Genel Müdürlüğü, Türkiye Geneli Sit Alanları İstatistikleri. http://www.kulturvarliklari.gov.tr/TR-44973/turkiye-geneli-sit-alanlari-istatistikleri.html, [10 Temmuz 2019].

Madran, E. (1989). Kentsel Korumada Değişik Yaklaşımlar Üzerine Düşünceler. Tarihi Kentlerde Planlama /Düzenleme Sorunları, Türkiyéde 11. Dünya Şehircilik Günü Kolokyumu, 6-8 Kasım 1987, Trakya Üniversitesi, Edirne, Bayındırlık ve İskan Bakanlığı.

Madran, E. (2006). Modern Mimarlı Ürünlerinin Belgelenmesi ve Korunması Süreci için Bazı Notlar. Mimarlık, 332 /Kasım-Aralık. http://www. mimarlikdergisi.com/index.cfm?sayfa $=$ mimarlik $\&$ DergiSayi $=50 \&$ Rec ID $=1207$

Mağmumi, Dr. Ş. (2008). Bir Osmanlı Doktorunun Seyahat Anıları: Yüzyıl Önce Anadolu ve Suriye. (Yay. Haz. C. Kayra). İstanbul: Boyut Yayınları.

Özdoğan, M. (2006). Arkeolojinin Politikasi ve Politik Bir Araç Olarak Arkeoloji, İstanbul, Arkeoloji ve Sanat Yayınları.

Özgen, H. M. (2018). "Adramytteion'dan Ioannes VIII (Xiphilinos) Konstantinopolis Patriklik Mührü Buluntusu ve "E Yapısı" İkincil Kullanımı”, Ege Dünyası Liman Kentleri, Sikke Mühür ve Ağırlıkları / Port Cities of the Aegean World Coins, Seals and Weights, Manisa, 243-255.

Özgen, H. M. (2016). “Adramytteion (Ören) 2015 Çalışmaları́nın Ardından”. Türk Eskiçağ Bilimleri Enstitüsü Haberler.. No.41. (Ocak 2016). s. 22 25.

Özgen, H. M. (2014). "Adramytteion (Ören) Kazı ve Onarım Çalışmalar1-2013". Türk Eskiçağ Bilimleri Enstitüsü Haberler. No. 37. (Ocak 2014). s. 23-28.

Özgen, H. M. (2013a) "Ören Arkeolojik Sit Alanına İlișkin Araștırmalar ve Kazı Sonuçları", Burhaniye / Ören Adramytteion Arkeolojik Sit Alanı Koruma Amaçlı İmar Planı. Analitik Etüdler. Cilt II. Planlama Alanına İlişkin Araștırmalar. (Yayınlanmamıș rapor). Promer Planlama, 15-39.

Özgen, H. M. (2013b) “Adramytteion (Ören) Kazıları́na Başlarken”. Türk Eskiçağ Bilimleri Enstitüsü Haberler. No. 36. (Mayıs 2013). s. 4-13. 
Pickard, R. (2001). Policy and Law in Heritage Conservation. Taylor \& Francis, Vol. 1.

Pirî Reis. (1988). Kitab-1 Bahriye. (Yay. Haz.:Ökte, E. Z.). 1. Cilt. Kültür ve Turizm Bakanlığı, Tarihi Araştırmalar ve Dokümantasyon Merkezleri Kurma ve Geliştirme Vakfi. İstanbul: İstanbul Araştırma Merkezi.

Rothschild, A. ve Wall, D. (2008). Urban Archaeology. Pearsall, Deborah M, (Ed). Encyclopedia of Archaeology içinde. Elsevier.

Savrum Kortanoğlu, M. (2014). "Arkeolojik Alanlarda Organizasyonel Bir Kavram Olarak Koruma”. Türk Eskiçağ Bilimleri Enstitüsü Haberler. No. 37. (Ocak 2014). s. 5-13.

Fayad, S., Bucklet, K. (2019). The transformational power of the HUL approach: Lessons from Ballarat, Australia, 2012-2017. Roders, P. A., Bandarin, F. (Ed). Reshaping UrbanConservation, The Historic Urban Landscape Approach in Action içinde (s.123-148). Singapur: Springer.

Stauber, J. (1996). Die Bucht von Adramytteion. IGSK 50, Bonn.

TBMM, (1999). 4434 Sayılı Arkeolojik Mirasın Korunmasına İlişkin Avrupa Sözleşmesi (Gözden Geçirilmiş)'nin Onaylanmasının Uygun Bulunduğu Hakkında Kanun. http://web.shgm.gov.tr/umevzuat/noneu/uygunbulma/belarus.pdf. [5 Eylül 2019]

Tekeli, İ. (1989). Kentsel Korumada Değişik Yaklaşımlar Üzerine Düşünceler. Tarihi Kentlerde Planlama /Düzenleme Sorunları, Türkiyéde 11. Dünya Şehircilik Günü Kolokyumu. 6-8 Kasım 1987. Trakya Üniversitesi, Edirne, Bayındırlık ve İskan Bakanlığı, 27-32.

Tuna, A., Erdoğan, E. (2016). Arkeolojik Sitlerin Sürdürülebilirliği Kapsamında Arkeolojik Parklar. Tekirdağ Ziraat Fakültesi Dergisi, Cilt 13. (2) s. $110-122$.

UNESCO, (1956). Arkeolojik Kazılara Uygulanabilir Uluslararası Prensipler Hakkında Tavsiye Kararı. http://www.unesco.org.tr/Pages/159/176/, [2 Kasım 2018].

UNESCO tavsiye kararı, (1976). Tarihî Alanların Korunması ve Çağdaş Rolleri Konusunda Tavsiye Karar1. http://www.unesco.org.tr/Pages/590/176, [20 Temmuz 2019]

UNESCO, (2005) Viyana Memorandumu. https://whc.unesco.org/en/documents/5965, [20 Eylül 2019]

UNESCO, (2011) Tarihi Kent Peyzajı Tavsiye Kararı. file://C:/Users/ admin/Documents/Makale_2018/Koruma\%20\%C4\%B0mar\%20 Plan\%C4\%B1/Literat\%C3\%BCr/HUL.pdf, [20 Eylül 2019]

Venedik Tüzüğü, (1964). www.icomos.org.tr > Dosyalar > ICOMOSTR_ tr0243603001536681730, [2 Kasim 2018] 